Review

\title{
Functionalization of Polymers and Nanomaterials for Biomedical Applications: Antimicrobial Platforms and Drug Carriers
}

\author{
Masoud Delfi ${ }^{1,+}{ }^{\text {, Matineh Ghomi }}{ }^{2,+}$, Ali Zarrabi ${ }^{3,4,+}$ (D) Reza Mohammadinejad ${ }^{5,+}$, \\ Zahra Baghban Taraghdari ${ }^{6,+}$, Milad Ashrafizadeh ${ }^{7}$ (D), Ehsan Nazarzadeh Zare ${ }^{8, *}$, \\ Tarun Agarwal ${ }^{9}\left(\mathbb{D}\right.$, Vinod V. T. Padil 10,*(D), Babak Mokhtari ${ }^{2}$, Filippo Rossi ${ }^{11}(\mathbb{D}$, \\ Giuseppe Perale ${ }^{12,13}$, Mika Sillanpaa 14,15,16,17 , Assunta Borzacchiello ${ }^{18}$,

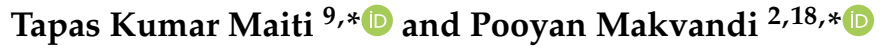

1 Department of Chemical Sciences, University of Naples “Federico II", Complesso Universitario Monte S. Angelo, Via Cintia, 80126 Naples, Italy; Masoud.delfi@unina.it

2 Chemistry Department, Faculty of Science, Shahid Chamran University of Ahvaz, Ahvaz 6153753843, Iran; ma_gh@rocketmail.com (M.G.); bmokhtari4@gmail.com (B.M.)

3 Sabanci University Nanotechnology Research and Application Center (SUNUM), Tuzla 34956, Istanbul, Turkey; alizarrabi@sabanciuniv.edu

4 Center of Excellence for Functional Surfaces and Interfaces (EFSUN), Faculty of Engineering and Natural Sciences, Sabanci University, Tuzla 34956, Istanbul, Turkey

5 Pharmaceutics Research Center, Institute of Neuropharmacology, Kerman University of Medical Sciences, Kerman 76169-13555, Iran; r.mohammadinejad87@gmail.com

6 Department of Chemical, Materials \& Industrial Production Engineering, University of Naples Federico II, 80125 Naples, Italy; z.baghban@studenti.unina.it

7 Department of Basic Science, Faculty of Veterinary Medicine, University of Tabriz, Tabriz 51666-16471, Iran; dvm.milad1994@gmail.com

8 School of Chemistry, Damghan University, Damghan 36716-41167, Iran

9 Department of Biotechnology, Indian Institute of Technology, Kharagpur 721302, India; tarun3agarwal5@gmail.com

10 Department of Nanomaterials in Natural Sciences, Institute for Nanomaterials, Advanced Technologies and Innovation (CXI), Technical University of Liberec (TUL), Studentská 1402/2, 46117 Liberec, Czech Republic

11 Department of Chemistry, Materials and Chemical Engineering, Politecnico di Milano Technical University, 20133 Milano, Italy; filippo.rossi@polimi.it

12 Faculty of Biomedical Sciences, University of Southern Switzerland (USI), Via G. Buffi 13, 6900 Lugano, Switzerland; giuseppe.perale@supsi.ch

13 Ludwig Boltzmann Institute for Experimental and Clinical Traumatology, Donaueschingenstrasse 13, 1200 Vienna, Austria

14 Institute of Research and Development, Duy Tan University, Da Nang 550000, Vietnam; mikaetapiosillanpaa@duytan.edu.vn

15 Faculty of Environment and Chemical Engineering, Duy Tan University, Da Nang 550000, Vietnam

16 School of Civil Engineering and Surveying, Faculty of Health, Engineering and Sciences, University of Southern Queensland, West Street, Toowoomba, QLD 4350, Australia

17 Department of Chemical Engineering, School of Mining, Metallurgy and Chemical Engineering, University of Johannesburg, P. O. Box 17011, Doornfontein 2028, South Africa

18 Institute for Polymers, Composites, and Biomaterials (IPCB), National Research Council (CNR), 80125 Naples, Italy; bassunta@unina.it

* Correspondence: ehsan.nazarzadehzare@gmail.com (E.N.Z.); vinod.padil@tul.cz (V.V.T.P.); maititapask@gmail.com (T.K.M.); pooyan.makvandi@ipcb.cnr.it or Pooyanmakvandi@gmail.com (P.M.)

+ Equaul co-first author.

Received: 21 May 2020; Accepted: 19 June 2020; Published: 23 June 2020

Abstract: The use of polymers and nanomaterials has vastly grown for industrial and biomedical sectors during last years. Before any designation or selection of polymers and their nanocomposites, 
it is vital to recognize the targeted applications which require these platforms to be modified. Surface functionalization to introduce the desired type and quantity of reactive functional groups to target a cell or tissue in human body is a pivotal approach to improve the physicochemical and biological properties of these materials. Herein, advances in the functionalized polymer and nanomaterials surfaces are highlighted along with their applications in biomedical fields, e.g., antimicrobial therapy and drug delivery.

Keywords: drug delivery; surface functionalization; antibacterial activity; antimicrobial properties; polymeric nanoparticles

\section{Introduction}

Polymers are the most used compounds which possess many advantages, such as lightweight materials, cheap, easy to produce as different products, and long durability [1]. To improve the applicability and specificity of polymers, some modifications to the particles are needed. These changes can be made in the bulk of the carrier, like incorporating $\mathrm{Cu}$ in nanospheres to enhance imaging and photocatalytic properties [2]. Another major site of modification is the surfaces of the polymers. Dry surface treatment techniques e.g., corona discharges [3], oxygen plasma [4], ultraviolet light-ozone [5], and cold atmospheric jet [6] have been applied for improving polymer/polymer or polymer/ceramic adhesions. To make corrections in the polymer surfaces, wettability properties of polymers can be altered to govern the adhesion of various coatings. This means the ability of the liquid for moistening the surface of a polymer, which in turn, creates different coatings on the surface. It is worth noting that polymers often have very poor wetting properties that prevent the coatings from sticking properly [7]. In this regard, surface tension plays a critical role on the surface wettability of the polymers, while low surface tension creates less wetting tendency. The attractive forces that exist on the microscopic scale of polymer surface molecules or atoms, prevent them from leaving the surface of solid/liquid materials. These forces are dependent on the binding energy of the atoms/molecules in the solid/liquid materials and cause the surface energy to disperse. For catching the high wettability on the polymer surfaces, a high concentration of polar components should be induced [8].

For improving the various properties (e.g., thermal, mechanical, and optical) of polymers, they can be combined with nanoparticles and nanofillers to form nanocomposites. Nanoparticles can modify the wetting tendency of polymer surfaces through two mechanisms. (I) Alterations of the intermolecular interactions of interfacial solid-water and enhancing the wettability of the polymer surface through modifying the chemical composition, (II) addition of some nanoparticles that can increase the hydrophobicity or water-repellence of the polymers via modification of the surface morphology (e.g., surface roughness) [9].

The physical and chemical properties of the polymer surfaces can be modified by the mentioned methodology for intimate interfacial contacts between two different phases, while these modifications have no effect on the properties of the bulk. These surface treatments show significant efficiencies such as (I) alteration of the chemical structure of polymer surfaces by free-radical reactions of the polymer surface with the surrounding gases, (II) etching of a microscopic layer or selective leaching of polymeric chains with low molecular weight, (III) polymer reinforcement by increasing the cross-links or branching of the polymer molecules, and (IV) cleaning by converting liquid or solid films/contaminants into volatile gas products $[10,11]$. 
The purpose of this review is to introduce the advances in surfaces functionalization of polymer and nanomaterials and discuss their recent investigations toward antibacterial modification and drug delivery (Figure 1).

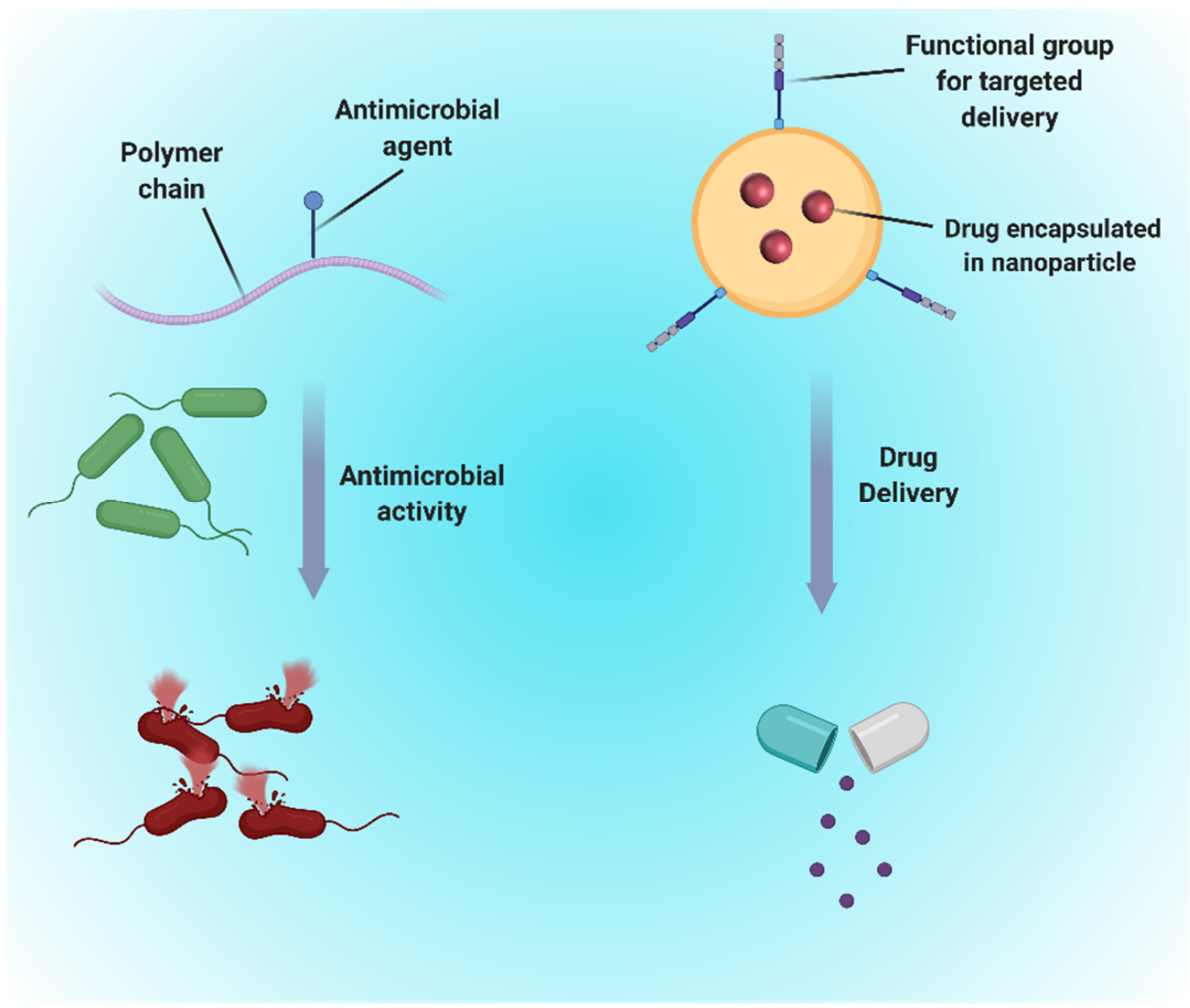

Figure 1. Surfaces functionalization of polymer and nanomaterials for antimicrobial therapy and drug delivery applications.

\section{Antimicrobial Therapy}

Humans are always exposed to the threat of microbial infections regardless of place and time $[12,13]$. There are three ways to impart antimicrobial activity to a platform (Figure 2). The first is functionalization of polymers or nanomaterials with antimicrobial agents, e.g., quaternary ammonium compounds (QACs) $[14,15]$. These compounds have been extensively used to improve the antimicrobial efficacy of various surfaces through a contact-killing mechanism. QACs, in particular the ones possessing long alkyl chains, are mostly utilized as antimicrobial and disinfectant materials. These compounds exhibit strong toxicity against fungi and amoebas, and have the ability to envelop viruses as well $[15,16]$. Another example that can be mentioned in this context is the surface modification of polysaccharides using QACs. Due to the available functional groups of polysaccharides, they are known as abundant renewable bio-substrates. For instance, glycidyl trimethyl ammonium chloride grafted cellulose and chitosan films have been investigated extensively as antibacterial surfaces [17-19]. 


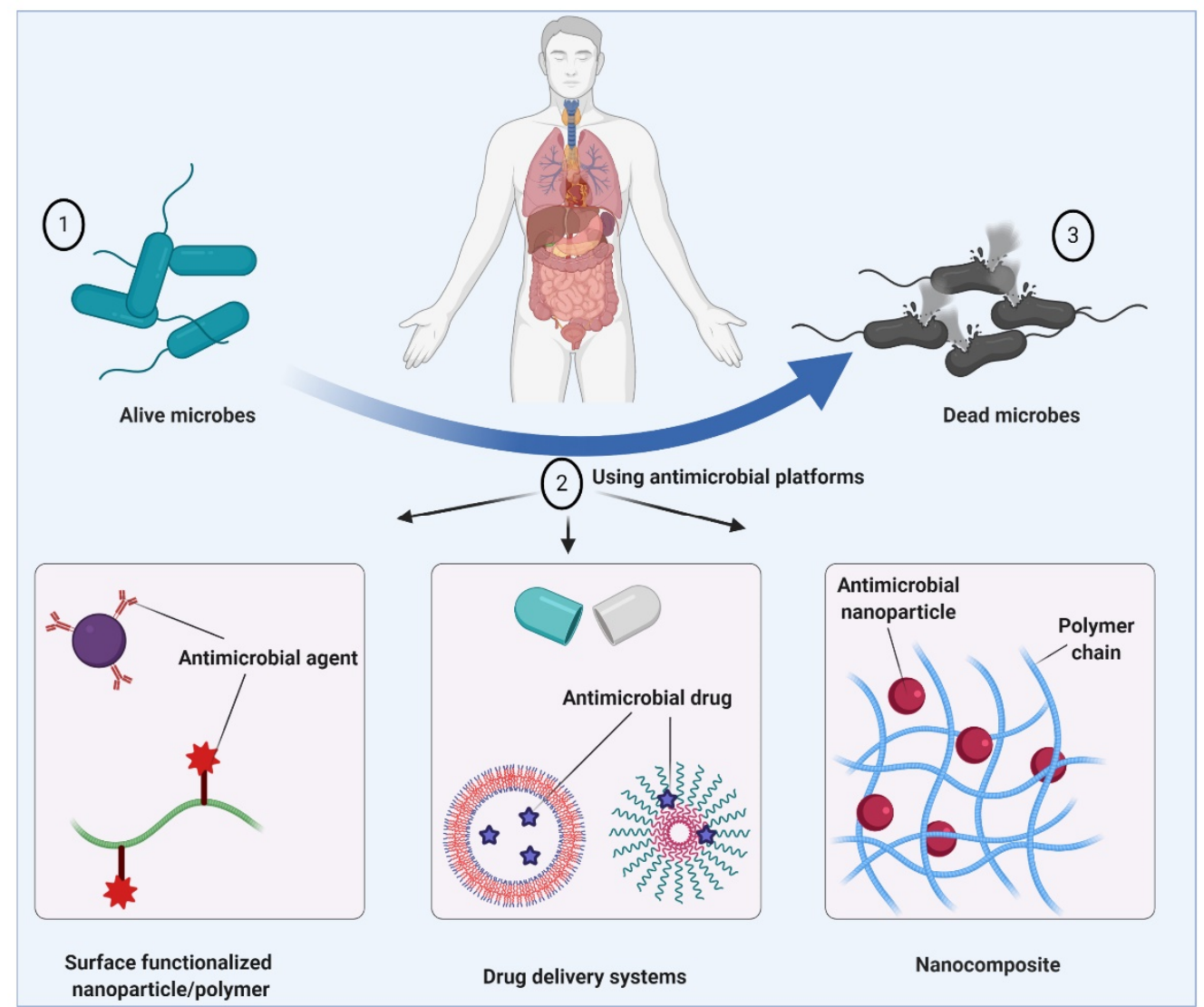

Figure 2. Schematic illustration of three ways of antimicrobial activity in a platform: (left panel) surface functionalization of nanoparticles/polymers, (middle panel) drug delivery system, and (right panel) fabrication of nanocomposite.

The second approach is fabrication composites by adding fillers such as metal-based nanomaterials like Ag nanoparticles [20-22]. Silver has been used for wound healing soon after its discovery as an effective antimicrobial agent. It can be used as a solid state (powder) or even salt solutions for wound treatment $[23,24]$. Although it has been used for a very long time, the exact mechanism of action of silver nanoparticles remained partially unknown. The antimicrobial activities of Ag NPs can be divided into four steps: approaching to the bacterial surface, disruption of the cell wall of the bacteria and its membrane through changing its permeability, exerting toxicity effects and oxidative stress by producing ROS and free radicals, and modulation of signal transduction pathways [25].

The last method is encapsulation of antimicrobial drugs or biomolecules such as gentamicin. The drug is a potent broad-spectrum antibiotic with high toxicity efficacy against various Gram-positive and Gram-negative organisms [26].

Regarding the killing strategy, there are two main strategies to confront bacteria: (I) releasing of antibacterial agents on the infected sites and (II) attaching to surfaces containing antibacterial compounds (contact-killing). In the latter strategy, surface modification of metallic or polymeric surfaces is performed to attach various agents with antibacterial activities to make direct contacts with microorganisms. To increase the antimicrobial efficacy, implant functionalization using antimicrobial peptides (AMPs) has been introduced to be a very practical technique. An interesting example in this respect, a polydopamine coated Ti substrate was conjugated with AMPs through a click chemistry reaction (Figure 3). The AMPs show resistance against the infection of different types of microbes including bacteria and fungi. They can penetrate the bacterial cell membrane and damage the drug-resistant bacteria vigorously. The surfaces functionalized by AMP showed high microbicidal effects with low cytotoxicity [27]. 


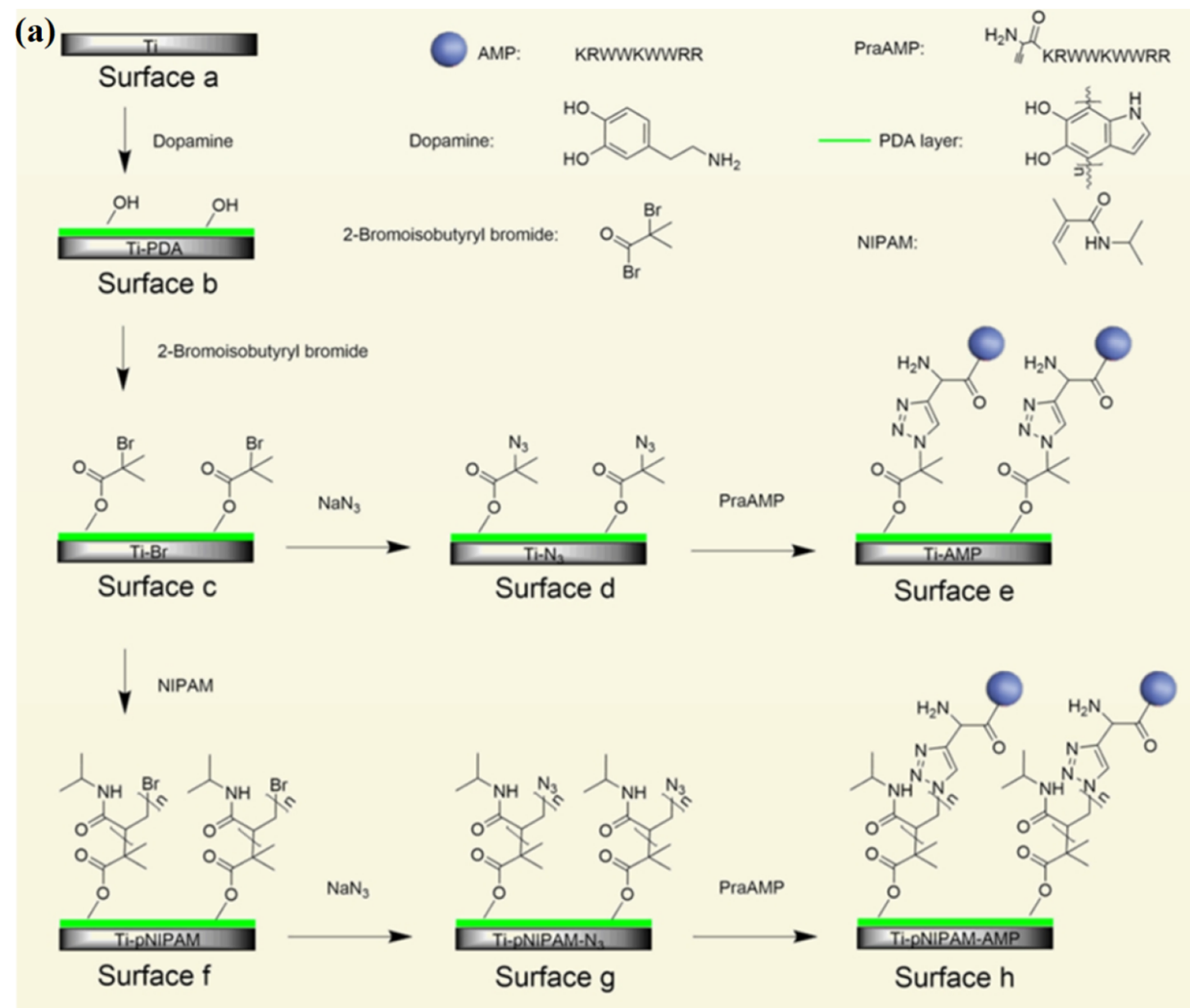

(b)
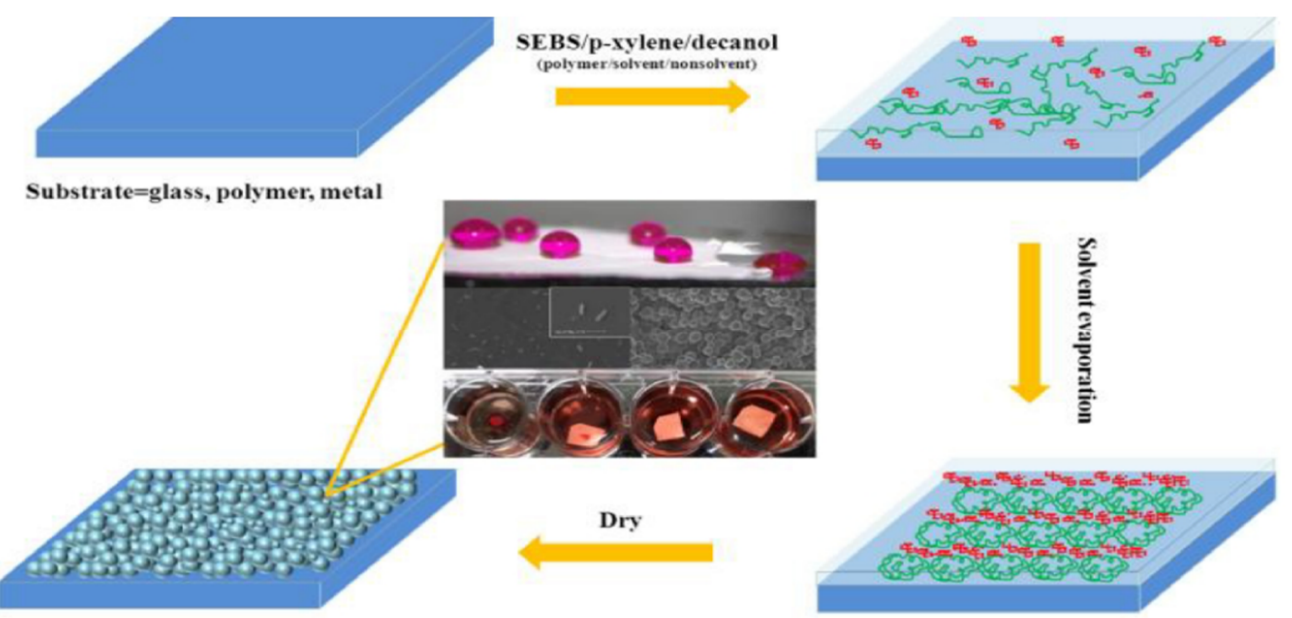

SEBS bead

SEBS chain \% decanol (nonsolvent)

p-xylene (solvent)

Figure 3. (a) Schematic of preparation of antibacterial implants through conjugation of antimicrobial peptides (AMPs) on Ti substrate. Reprinted with permission from [27]. (b) Schematic of preparation of biocompatible and antibacterial surfaces by superhydrophobic coating of styrene-b-(ethylenecobutylene)-b-styrene elastomer (SEBS) on different substrates. Reprinted with permission from [28].

There are some ceramic nanocompounds, e.g., $\mathrm{SiO}_{2}$ nanoparticles, that do not possess antimicrobial activity yet have been modified to generate microbicidal materials. As an example, Makvandi et al. have functionalized silica nanoparticles with quaternary ammonium methacrylate blended with 
bis-GMA/TEGDMA, creating a polymerized nanocomposite showing high antimicrobial activities. The photocurable $\mathrm{SiO}_{2}$ nanoparticles contain two functional groups: quaternary ammonium compound as an antimicrobial agent and methacrylate monomers that co-polymerize with the organic polymer matrix [29].

Copper nanoparticles have also shown great antibacterial activities, which is why they have received much attention lately. Their toxicity against some bacteria is due to the small size of copper molecules endowed by high surface-to-volume ratio. These two main properties allow them to interact with the membrane of the microbial from close distance. Copper nanoparticles have been designed to confront some cell lines such as Micrococcus luteus, S. aureus, Escherichia coli, K. pneumoniae, P. aeruginosa, and three fungal strains [30]. The mechanism of action of copper nanoparticles includes interactions between the released ions from the copper molecules and binding to the DNAs [31] (Figure 4).
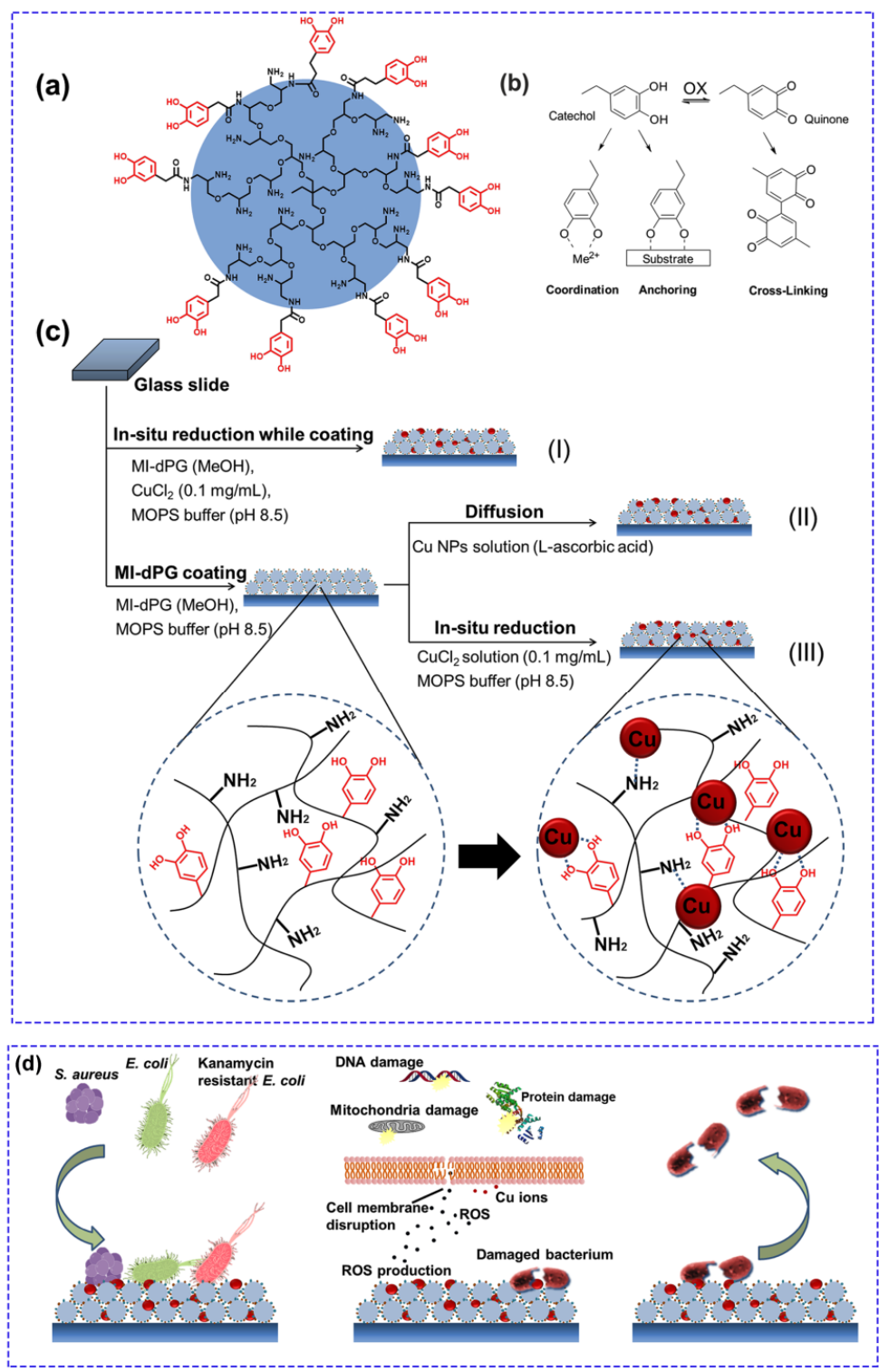

Figure 4. In situ formation of $\mathrm{Cu}$ nanoparticles within mussel-inspired dendritic polyglycerol (MI-dPG) as functional coatings with durable and broad-spectrum antimicrobial activity. (a) Chemical structure of MI-dPG. (b) Mechanism of catechol anchoring and crosslinking. (c) Preparation of $\mathrm{Cu}$ nanoparticle-incorporated MI-dPG surface coatings using 3 different methods. MOPS: 3-(N-morpholino)-propanesulfonic acid. (d) Schematic of contact killing of bacteria on a Cu nanoparticle-incorporated MI-dPG surface coating via an "attract-kill-release" mechanism. Reprinted with permission from [32]. 
Hydrophobic nature of some polymers containing surface-free functional groups such as polyethylene (PE), polypropylene (PP), polystyrene (PS), etc., which are in contact with biological systems, have shown high susceptibility for microbial growth. Chemical etching via surface oxidation and morphological changes is a way to alter the hydrophobicity of these polymer surfaces. Moreover, various radiation sources such as infrared, visible light, ultraviolet, $\gamma$ radiation, microwave plasma, and high energy electrons have been mostly used to graft species and monomer to/from the surface [33]. Reactions mediated by microwave plasma surface, which is a fast, solvent free, and sterile approach, provide covalent linking carboxylic acid groups to almost any polymer substrate. Moreover, a number of researchers have used an excited ionized gas to produce reactive functional groups which provide controllable conditions for desirable covalently linking compounds. For instance, when maleic anhydride is applied as a monomer, the resultant surface modification is to form - $\mathrm{COOH}$ entities which linked to a polymer backbone. According to the scheme shown in Figure 5, PE/PP surface functionalization is carried out through a simple two-step process: (a) microwave plasma reactions that lead to the - $\mathrm{COOH}$ formation on the surface and (b) covalent attachment of alkyne moieties. After this surface treatment, the polymer surface is ready for further modification and attaching antimicrobial agents. This approach was used for the attachment of antibiotics, such as ampicillin to provide microbicidal properties on the surface of PP and PE substrates. These modified surfaces revealed strong antibacterial effects against $S$. aureus [33]. Some of the other antibiotics like cephalexin, amoxicillin, methicillin, and vancomycin were also attached to the various surfaces to provide active surfaces [34,35]. For example, amoxicillin-grafted bacterial cellulose sponges were prepared for antibacterial materials and wound healing applications [35].

(a)

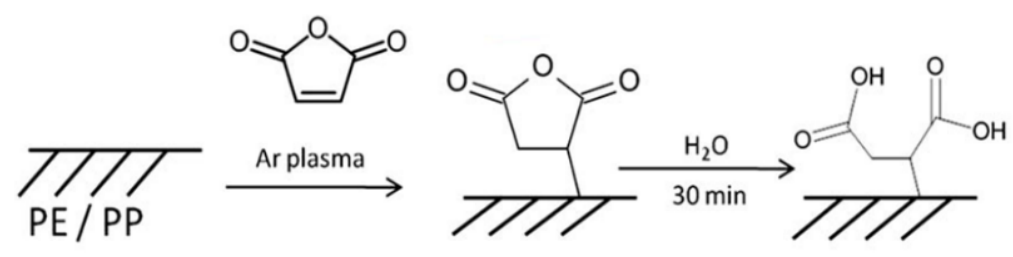

(b)
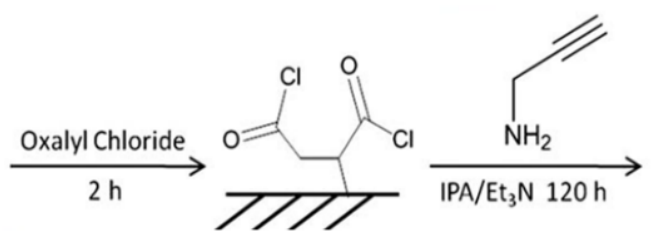

(c)

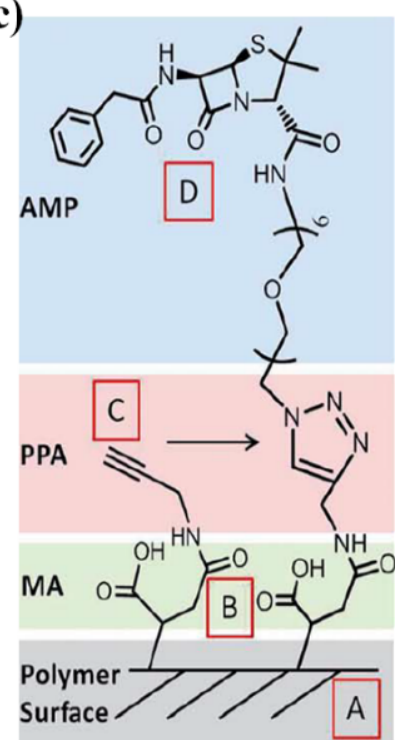

Figure 5. (a) PE/PP surface functionalization through microwave plasma in the presence of maleic anhydride (b) followed by alkyne attaching procedure using propargylamine. (c) Ampicillin grafting via click reaction. Reprinted with permission from [33]. 
An interesting example is poly (propylene carbonate) (PPC), which is a partially renewable polymer produced by $\mathrm{CO}_{2}$ and can be degraded into $\mathrm{CO}_{2}$ and $\mathrm{H}_{2} \mathrm{O}$. The functionalization of PPC surface raises its applications in food industries as a biodegradable packaging agent. Plasma coating has also been employed for chemical immobilization of thymol, a natural microbicide, on the surface of the PPC. The highest antibacterial effect was obtained for $1.25 \mathrm{mg} / \mathrm{cm}^{2}$ thymol with high intensity plasma for $15 \mathrm{~min}$. In water media, the antibacterial effect of the thymol-decorated PPC preserved for one week, whereas under dry conditions, the properties maintained for several months [36].

Other polymers such as polydopamine have been utilized as a coating agent for polyurethane (PU) surfaces. The perfluoroalkyl-functionalized surface exhibited strong antifouling properties, whereas the coatings containing Ag nanoparticles (NPs) showed biocidal activity. However, the polydopamine coated PU films decorated with both the Ag NPs and perfluoroalkyl exhibited high antibacterial effect toward gram-positive and gram-negative bacteria [37].

Another brilliant antibacterial agent are QACs (dimethyloctadecyl [3-(trimethoxysilyl) propyl] ammonium chloride), which can be coated by polyethylene (PE) and polystyrene (PS). The QACs-decorated PE and PS surfaces exhibited antibacterial activity against Salmonella enterica (a Gram-negative bacterium). However, the antibacterial efficiency of the QACs-decorated PS was higher in comparison with QACs-decorated PE, which is attributed to the higher density of active sites. The functionalized surface with short alkyl chain, e.g., methyl $\left(C_{1}\right)$ consisting of trimethyl [3-(trimethoxysilyl) propyl] ammonium chloride, did not display considerable antibacterial effects offering the importance of alkyl chain length. This technique presents a suitable approach for developing antibacterial hydrocarbons with contact active sites [38].

Apart from the polymeric surfaces, the surface of stainless steel has also been functionalized by antimicrobial moieties. In this respect, Bastarrachea et al. prepared the covalent surface functionalization of the stainless steel including antibacterial $N$-halamine groups [39]. Multilayers of poly (acrylic acid) and polyethyleneimine were attached onto the surface of stainless steel by layer-by-layer technique. The steel functionalized through $N$-halamine exhibited antibacterial effect (99.7\% reduction) toward Listeria monocytogenes [39].

The use of surface functionalized polymer-based nanocomposites has increased significantly in a wide range of applications for different fields. A practical application of this category of nanomaterials is the design and production of firm superamphiphobic fabric with a new and automatic self-healing property caused by chemical materials. The product is generated by a two-step wet-chemistry coating technique using widely available fluoro-included polymer, poly(vinylidene fluoride-co-hexafluoropropylene) (PVDF-HFP), fluoroalkyl silane (FAS), and modified silica nanoparticles. According to the mechanical evaluations, the fabrics could tolerate over 600 cycles of standard laundry and about 8000 cycles of abrasion with no superamphiphobicity changes. Furthermore, the coating showed high stability against acid/base chemicals, ozone, and boiling process. In the case of damaging the fabric by chemicals, the coating can be repaired using brief heating treatments (Figure 6) [40]. 


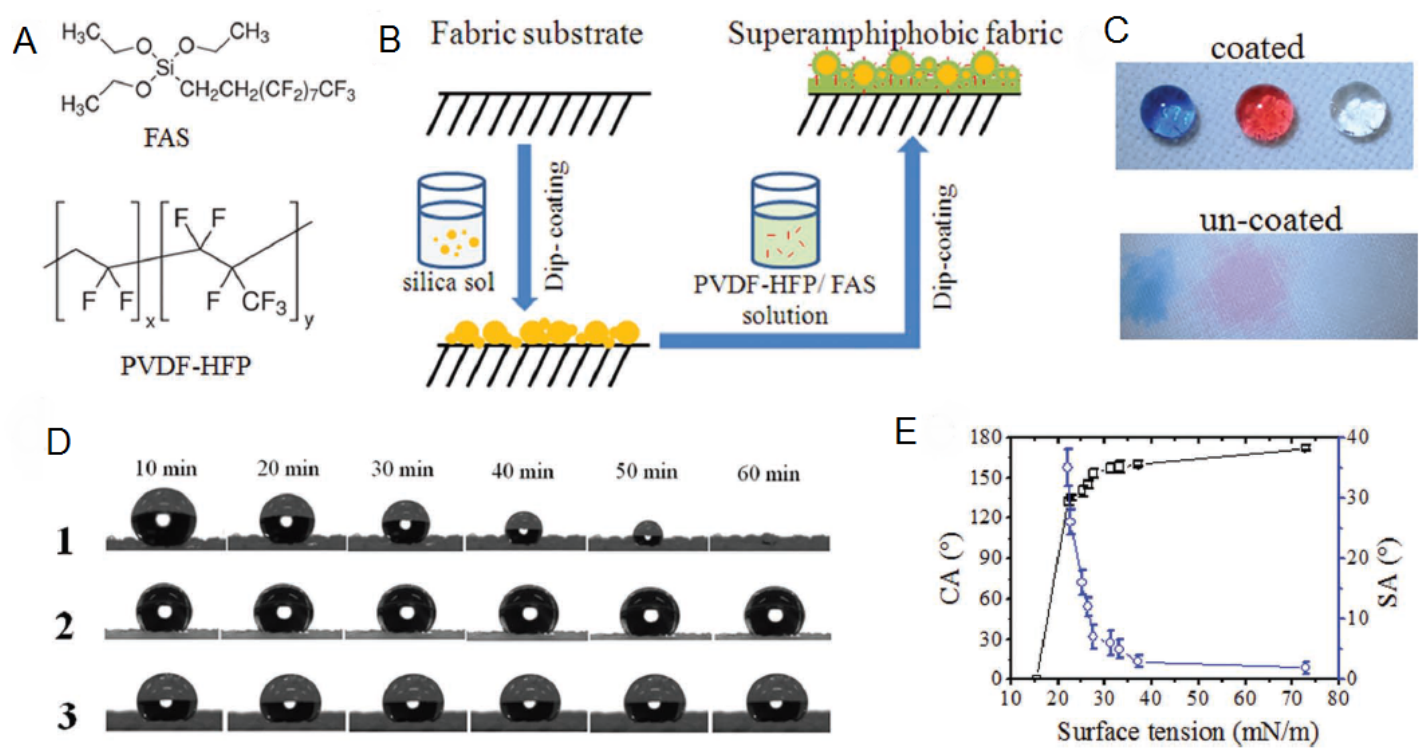

Figure 6. (A) Chemical structure of fluoroalkyl silane (FAS) and poly(vinylidene fluoride-cohexafluoropropylene) (PVDF-HFP). (B) Coating procedure for superamphiphobic fabrics. (C) Photograph of blue-colored water, red-colored hexadecane and clear soybean oil on the coated and un-coated polyester fabrics ( $10 \mu \mathrm{L}$ for each drop; the small amount of dye used, oil blue in water and oil red in hexadecane, had no influence on the contact angles). (D) Variation of liquid drops with time: (1) water, (2) soybean oil, and (3) hexadecane. (E) Dependency of contact angle (CA) and sliding angle (SA) on the surface tension of liquids. Reprinted with permission from [40].

Surface functionalized polymers have been also applied for industrial purposes. Recently, high-lignin-content lignin-based rigid polyurethane (RPU) was developed using lignin surface functionalization with polyisocyanate [41]. RPU foams are considered the most applied polymeric materials for construction applications such as wall panels, flooring, and structural insulated panels, and that is due to their excellent features including high thermal insulation, wonderful mechanical properties, low density, and etc. [42]. As a result of such modifications, RPU foams produced with $30 \%$ more lignin instead of petroleum-based polyol displayed approximately similar thermal and mechanical properties in comparison with the traditional RPU foams. However, the performance of surface functionalized lignin-based RPU foams developed by $50 \%$ in terms of specific compressive strength. The outcome displays an increase in the reactivity and homogeneity of the surface functionalized lignin-based RPU foams compared to non-functionalized lignin-based RPU foams. Also, the thermal insulation and thermal stability of both categories of foams were comparable. It is very important to mention that the newly designed lignin-based RPU foams showed fewer environmental impacts compared to the conventional RPU foams [41]. In Table 1, a list of antimicrobial polymers and nanocomposite applied in different biomedical applications is presented.

In addition to natural and synthetic materials found to exert bactericidal activity by mechanical rupture, some insects i.e., dragonflies have been discovered to possess nanoprotrusions on their wings, inducing antibacterial activities on contact. This discovery has led to design and creation of bactericidal implant surfaces by insect wing-imitating nanopillars fabricated from synthetic materials. According to the results of physiological and morphological investigations performed on mimetic titanium nanopillars, the nanopillars could induce oxidative stress leading to deformation and penetration of the Gram-positive and Gram-negative bacterial cells upon contact [43]. Also, biofilm formation on biomedical implants and surgical instruments available in hospitals and clinics has always been a challenging matter for being a high-cost maintenance procedure. To circumvent this inconvenience, copper nanowhiskers were used to produce antibacterial surfaces by molecular beam epitaxy technique. In addition, hydrophobicity of water droplets in the Wenzel regime is responsible of controlling the biological response that brings mechanical injury and death to the cells [44]. 
Table 1. Antimicrobial polymers and nanocomposites used in biomedical applications.

\begin{tabular}{|c|c|c|c|c|c|}
\hline Platforms/Materials & Antimicrobial Agent & Strategy & Application & Remarks & Ref \\
\hline Hyaluronic acid hydrogel & $\begin{array}{l}\text { Quaternary ammonium } \\
\text { compounds }\end{array}$ & Contact killing & Wound healing & $\begin{array}{l}\text { The hydrogel showed } \\
\text { antibacterial activity } \\
\text { against bacteria }\end{array}$ & [45] \\
\hline $\mathrm{Fe}_{3} \mathrm{O}_{4}$ & $\begin{array}{c}\text { Quaternarized } \\
N \text {-halamine polymers }\end{array}$ & Contact killing & $\begin{array}{l}\text { Water purification } \\
\text { systems and } \\
\text { household sanitation }\end{array}$ & $\begin{array}{l}\text { Effective antimicrobial impact } \\
\text { against Staphylococcus aureus } \\
\text { and Escherichia coli } \\
\text { (gram-negative) }\end{array}$ & [46] \\
\hline $\begin{array}{l}\text { Titanium dioxide core- } \\
\text { shell nanoparticles }\end{array}$ & $N$-halamine & Drug release (Cisplatin) & Anticancer & $\begin{array}{l}\text { The nanoparticles showed } \\
\text { effective antimicrobial activities } \\
\text { against } S \text {. aureus and } E \text {. coli }\end{array}$ & [47] \\
\hline $\begin{array}{l}\text { Silica nanoparticles with nitric } \\
\text { oxide (NO) release capabilities }\end{array}$ & $\begin{array}{l}\text { Quaternary ammonium } \\
\text { compounds }\end{array}$ & Drug release (Nitric oxide) & Infection therapy & $\begin{array}{l}\text { Very high bactericidal efficacy } \\
\text { against } S \text {. aureus and } \\
\text { P. aeruginosa }\end{array}$ & [48] \\
\hline $\begin{array}{c}\text { Polyethyleneimine (PEI), } \\
\text { polyvinylpyrrolidone (PVP) } \\
\text { and poly (2-vinyl pyridine)- } \\
\text { b-poly(ethylene oxide) } \\
\text { (PEO-b-P2VP) }\end{array}$ & silver colloids & Contact killing & $\begin{array}{l}\text { Antibacterial and } \\
\text { antifungal }\end{array}$ & $\begin{array}{l}\text { The materials exhibited high } \\
\text { biocides against fungus } \\
\text { and bacteria }\end{array}$ & [49] \\
\hline Chitosan & Silver nanoparticles & Contact killing & Infection therapy & $\begin{array}{l}\text { Very high antimicrobial impact } \\
\text { against } E . \text { coli and S. aureus }\end{array}$ & {$[50]$} \\
\hline Polyethylenimine (PEI) & Silver nanoparticles & Contact killing & Infection therapy & $\begin{array}{l}\text { PEI-Ag nanoparticles showed } \\
\text { effective antibacterial activity }\end{array}$ & {$[51]$} \\
\hline $\begin{array}{c}\text { Porous amine-reactive (PAR) } \\
\text { polymer films from } \\
\text { poly(pentafluorophenyl } \\
\text { acrylate) (PPFPA) }\end{array}$ & $\begin{array}{l}\text { Porous amine-reactive } \\
\text { films incorporating } \\
\text { lubricant and } \\
\text { silver nanoparticles }\end{array}$ & Contact killing & Infection therapy & $\begin{array}{l}\text { This film showed a multimodal } \\
\text { anti-biofouling surface }\end{array}$ & {$[52]$} \\
\hline $\begin{array}{l}\text { Thin-film composite of } \\
\text { polyamide reverse } \\
\text { osmosis irreversible }\end{array}$ & Copper nanoparticles & Contact killing & RO desalination & $\begin{array}{l}\text { The functionalized membrane } \\
\text { exhibited significant } \\
\text { Antibacterial activity for three } \\
\text { different model } \\
\text { bacterial strains. }\end{array}$ & {$[53]$} \\
\hline
\end{tabular}


Table 1. Cont

\begin{tabular}{|c|c|c|c|c|c|}
\hline Platforms/Materials & Antimicrobial Agent & Strategy & Application & Remarks & Ref \\
\hline $\begin{array}{l}\text { Dopamine functionalized } \\
\text { polyimide films }\end{array}$ & Silver nanoparticles & Contact killing & Antibacterial & $\begin{array}{l}\text { Surface-silvered polymer film } \\
\text { showed the antibacterial } \\
\text { activity using Escherichia coli } \\
(\text { E. coli). }\end{array}$ & {$[54]$} \\
\hline $\begin{array}{c}\text { Poly(lactic-co-glycolic } \\
\text { acid)/ZnO nanorods/Ag NPs } \\
\text { Hybrid coating on Ti }\end{array}$ & $\begin{array}{l}\text { Silver nanoparticles and } \\
\text { ZnO nanowire }\end{array}$ & Contact killing & Antibacterial & $\begin{array}{l}\text { This platform exhibited high } \\
\text { potential for biomedical } \\
\text { application with excellent } \\
\text { biocompatibility and } \\
\text { self-antibacterial activity. }\end{array}$ & {$[55]$} \\
\hline $\begin{array}{l}\text { Biodegradable } \mathrm{Mg}-\mathrm{Cu} \\
\text { alloy film }\end{array}$ & $\mathrm{Mg}-\mathrm{Cu}$ alloy & Contact killing & Orthopedic infections & $\begin{array}{l}\text { The results indicated the } \\
\text { potential utility of this biofilm } \\
\text { in treatment of } \\
\text { orthopedic infections }\end{array}$ & {$[56]$} \\
\hline
\end{tabular}




\section{Drug Delivery}

For a successful drug or other biomolecule delivery, a specific dose of drug/biomolecule should be delivered at the targeted site during a desired period $[57,58]$. Aside from polymeric membrane, one method can be used for modification of nanomaterials, e.g., polymeric or metallic nanoparticles, in which polymeric compounds are applied to control the drug release in human body. A number of studies have confirmed the improvement of delivery efficiency using surface-functionalized nanostructures. The surface functionalization of polymeric nanomaterials can be classified into two categories as presented in Figure 7. In the first approach, a coupling agent is used for modification of the nanostructure and for that, at least one reactive group should be available on the surface of nanoparticles. The second is similar to the micellar formation of the amphiphilic block copolymers, having hydrophilic and hydrophobic segments such as pluronic, which is a polyethylene oxide-polypropylene oxide-polyethylene oxide copolymer (PPO-PEO-PPO). It is worth noting that such amphiphilic copolymers are used for preparation of thermosensitive injectable hydrogels for biomedical applications [59].

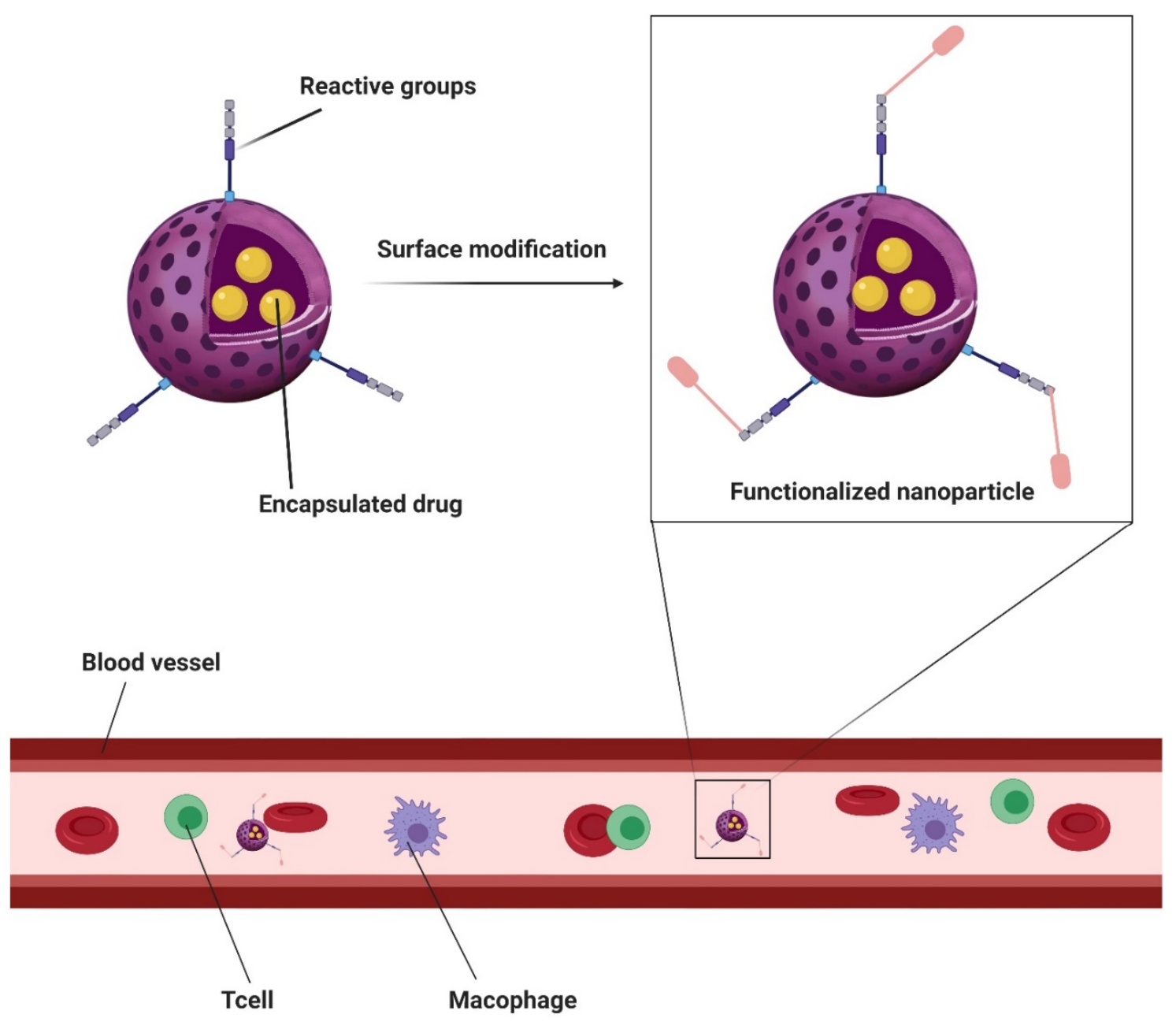

Figure 7. Schematic presentation of surface modification procedure for the purpose of surface functionalization of nanomaterials for targeted delivery applications. 
In general, the hydrophobic core gives a domain for the encapsulation of hydrophobic biomolecules, such as diclofenac; whereas the shell layer is directly contacted to body fluids and organs which are used for site specific delivery. For instance, nanoparticles of polylactic-co-glycolic acid (PLGA) have been functionalized using poly(ethylene)glycol for various purposes including enhancement for diffusion of PLGA NPs in human cervical mucus or better delivery of drugs/biomolecules [60,61].

As shown in Figure 6, there are chemical bonds formed between the polymeric nanostructure and functional moiety in the process of surface modification. Regardless of the surface functionalization which includes chemical linkages, there is another approach called surface coating which does not possess covalent bonds between the coated compounds and polymeric nanoparticles. As a matter of fact, the main drawback for using PLGA NPs for DNA/RNA delivery is their negative charge, which restricts the interactions with the negatively charged DNA as well as the poor transport ability of the DNA-loaded PLGA NPs through the cell membrane. With this in mind, many researchers have coated PLGA NPs using cationic polymers such as chitosan [62].

Some other types of nanostructures based on naturally occurring polymers, e.g., hyaluronic acid, have been decorated to improve their drug delivery capability. Besides polymeric nanomaterials, some metallic and ceramic ones have been extensively investigated as delivery vehicles of various biopharmaceuticals. However, to enhance their biocompatibility and upgrade some characteristics, the surface of these metal nanostructures has been modified. Gold nanoparticles have been functionalized by hyaluronic acid. Hyaluronic acid is naturally occurring glycosaminoglycan, present in mammalian connective tissues such as dermis, synovial fluids, vitreous body and nucleus pulposus, where it fulfills important biophysical and biological functions. As a drug delivery vehicle, a biocompatible linear polysaccharide of hyaluronic acid is highly efficient for site-specific delivery to tissues with HA receptors, such as hyaluronan receptor for endocytosis (HARE) and cluster determinant 44 (CD44) [63,64].

Functionalization of polymers can also improve the physicochemical properties of drug carriers. For example, cyclodextrin $(\beta C D)$ functionalized agarose (CFA) decreased the gelling and melting temperature of the conventional agaroses. CFA gels with low gelling temperature have been used for sustained release of DOX via inclusion complexation of $\beta C D$ [65].

Besides, the type of NPs has a dramatic effect on the efficacy and safety of cancer therapy. These results root from the difference in the nature of the nanoparticle material as a protective shell around the drug and altering pharmacokinetics of the therapeutics [66]. Besides, focusing on the other angle, stimuli-responsive drug delivery systems increase the efficacy and decrease the side effects of anticancer agents are attractive platforms for cancer therapy [67,68]. Functionalized polymers can be applied as stimuli-responsive drug carriers [69]. Recently, benzoic-imine cross-linked branched PEI-g-mPEG copolymer with hydrophobic terephthalaldehyde (TPA) molecules has been prepared to deliver indocyanine green (ICG). Cleavage of benzoic-imine bonds in the pH-responsive functionalized polymeric nanogels released ICG to improve tumor-targeted therapy [70] (Figure 7). Other $\mathrm{pH}$-responsive polymeric nanostructures can be prepared for conjugating of benzaldehyde with PEGylated amphiphilic block copolymers to specifically treat lung and ovarian cancer [71] (Figure 8).

To create the reactive oxygen species (ROS) and glutathione (GSH) responsive multifunctional platforms, an amphiphilic block copolymer has been functionalized with S-nitrosoglutathione (GSNO). These nanoparticles released DOX in a ROS triggered manner, selectively increased the accumulation of the drug inside the chemo-resistant cancer cell lines [72]. Furthermore, amine-functionalized copolymers containing redox-sensitive cross-linker have been used to prepare redox-sensitive degradable prodrug nanogels for intracellular DOX release. These biocompatible nanogels showed medium antitumor activity under a reductive environment in HeLa cells [73]. 
a)

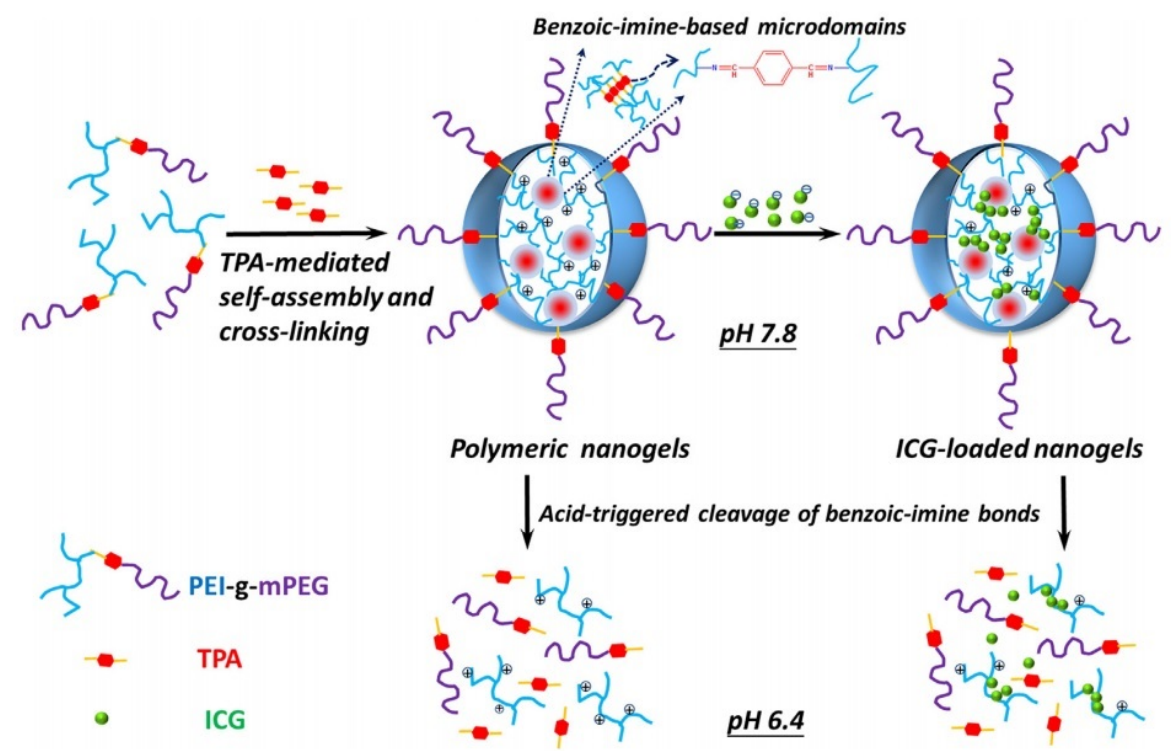

b)
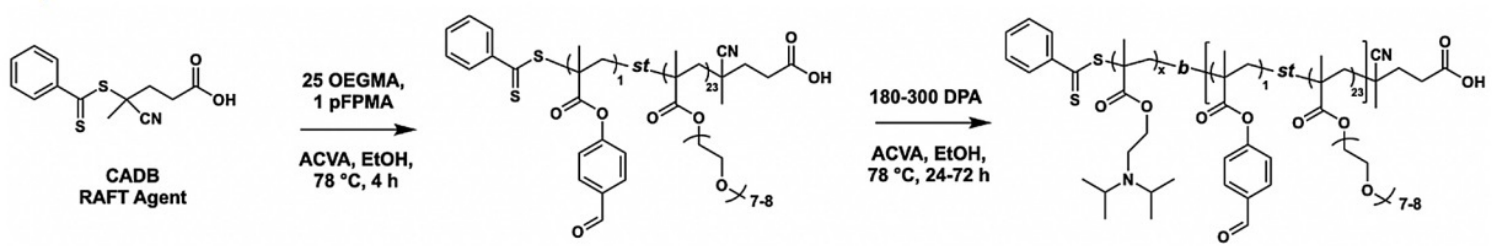

Figure 8. (a) Production of the $\mathrm{pH}$-responsive benzoic-imine functionalized for polymeric nanogels to deliver indocyanine green (ICG) [70]. (b) Synthesis of the p(oligo(ethylene glycol) methacrylatestpara-formyl phenyl methacrylate)P(OEGMA-st-pFPMA) macro-chain transfer agent (macro-CTA) and preparation of the benzaldehyde functionalized p(oligo(ethylene glycol) methacrylate-stpara-formyl phenyl methacrylate-b-poly(2-(diisopropylamino)ethyl methacrylate) P(OEGMA-st-pFPMA)-b-PDPA polymers. Reprinted with permission from [71].

Photo/thermo-responsive properties can be achieved after the functionalization of natural and synthetic polymers [74]. Thiourea-functionalized chitosan grafted by poly(L-lactide), poly(N-isopropylacrylamide), and poly(acrylamide) have been used to prepare Photo/thermo-triggered micelles. Conjugation of gold nanorods onto the micelles induces photo-sensitivity and the thermal shrinkage of the micelles triggers paclitaxel release for breast cancer therapy [75].

Anticancer drugs possessing off-target toxicity showed several disadvantages [76]. Thus, tumortargeted drug delivery mediated by nanoparticles is a promising strategy to fight cancer [77-79]. Particles can be modified with specific ligands expressing high affinity for their complementary receptor on the cell's surface. This active targeting delivery can improve the efficiency and safety of many therapies like cancer therapy [80].

Conjugation of polymers with targeting agents such as aptamers, antibody, folic acid, and proteins improve the tumor target ability in co-therapy [81,82]. Aptamers produced from nucleic acids, RNA, or DNA specifically bind to a ligand, like a cancer antigen, for targeting cancer cells [83]. These agents are used to improve the efficiency of drugs without harming the normal cells. Aptamer AS1411 functionalized polymeric nanoparticles containing poly (D,L-lactic-co-glycolic acid) (PLGA) and poly (N-vinylpyrrolidone) (PVP) were prepared against human lung cancer cells (A549). The DOX-loaded nanoparticles induced apoptotic cell death via the nucleolin receptor endocytosis and the treated animals were significantly recovered from cancer (Figure 9) [84]. 
a)

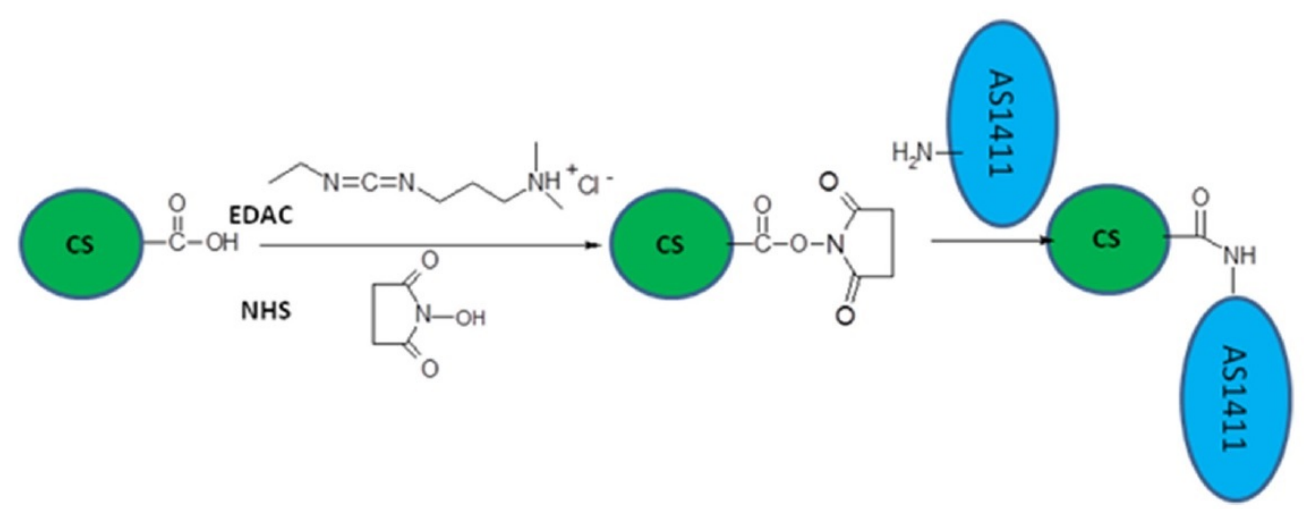

b)

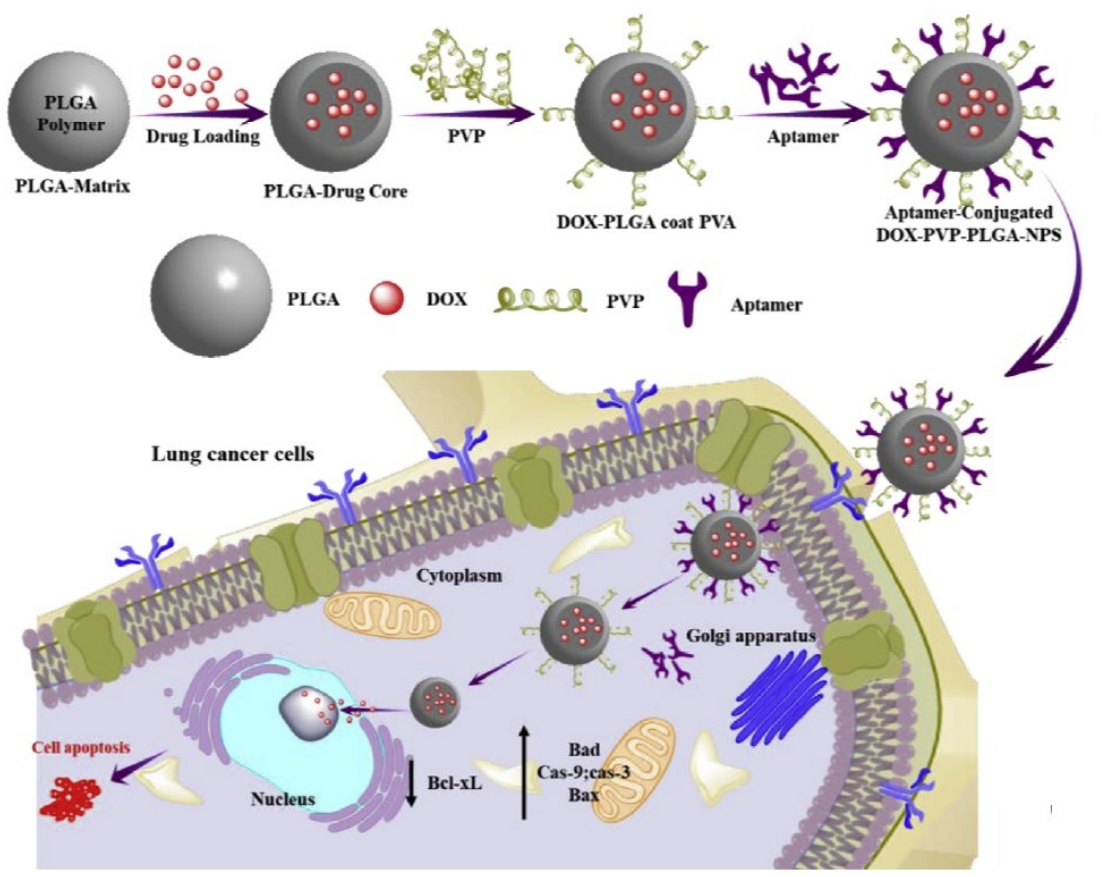

Figure 9. (a) Preparation of AS1411-functionalized carboxymethyl chitosan [85]. (b) Schematic illustration of uptake mechanism of AS1411-functionalized poly (D,L-lactic-co-glycolic acid)-poly (N-vinylpyrrolidone) (PLGA-PVP) nanoparticles delivering doxorubicin (DOX). Reprinted with permission from [84].

Furthermore, carboxymethyl chitosan nanocapsules (diameter varied between 100 and $267 \mathrm{~nm}$ ), functionalized with the aptamer enhancing the tumor recognition, improved the 5-fluorouracil (5-FU) treatment of breast cancer. The biocompatible 5-FU-loaded nanocapsules easily modulated cancer cell death in MCF-7 cell line [85]. In other research, the holo-transferrin and ovotransferrin functionalized drug-loaded polymeric structures have increased internalization in breast cancer cells [86]. In another study, targeted curcumin-loaded exosome in the treatment of ischemic stroke has shown great anti-inflammation and cell-survival in the damaged area. Although exosomes can cross the blood-brain barrier, the accumulation in the lesion region is not satisfactory. Binding cyclo(Arg-Gly-Asp-D-Tyr-Lys) peptide ( $\left(\right.$ RGDyK)) to the exosomes increased the adhesion to integrin $\alpha_{v} \beta_{3}$ in reactive cerebral vascular endothelial cells. The resulting cRGD-exosomes have almost 11-fold higher accumulation in the lesion region in comparison to non-ischemic parts [87].

One innovative targeting technique in cancer therapy is the modification of silica $(\mathrm{Si})$ particles by platelet membrane to target circulating tumor cells (CTCs). CTCs as metastasis agents should be neutralized to prevent spreading of cancer cells. One possible way, inspired by immune system cells' 
behavior, is to stimulate cell death by attaching apoptosis inducing ligand to the particles. Whereas having mobile target cells prevent applying common passive tumor targeting treatment. The alternative way of targeting roots from the transit behavior of CTCs in blood. CTCs create local thrombosis, attracting activated platelets to be protected from immune system. As a result, modification of Si NPs attached to apoptosis ligand with activated platelet membrane could decrease lung cancer metastasis by 8 times [88].

Diabetes is one of the major chronic disorders all around the world, requiring daily insulin injection to be controlled. Due to numerous disadvantages related to this method, a noninvasive insulin therapy route of administration can solve many problems in this area $[89,90]$. Oral insulin delivery is greatly favorable and desired since it mimics the physiological secretion of insulin. However, it has been extensively restricted due to its low bioavailability followed by low permeability, enzymatic degradation, and so on [91]. To elevate the bioavailability of oral delivery, the ligand-receptor binding seems a promising method. One solution to pass the endothelium is using the bile acid pathway (Figure 10). By functionalizing the chitosan NPs with deoxycholic acid, the particles containing insulin can be internalized via apical sodium-dependent bile acid transporter (ASBT)-mediated cells. Besides, the NPs can be protected from lysosomal degradation inside the cell by binding to cytosolic ileal bile acid-binding protein (IBABP). The result showed an elevated bioavailability to almost $16 \%$ and maintained blood glucose at low levels for almost half a day, compared to only $6 \mathrm{~h}$ in subcutaneous injection [92].

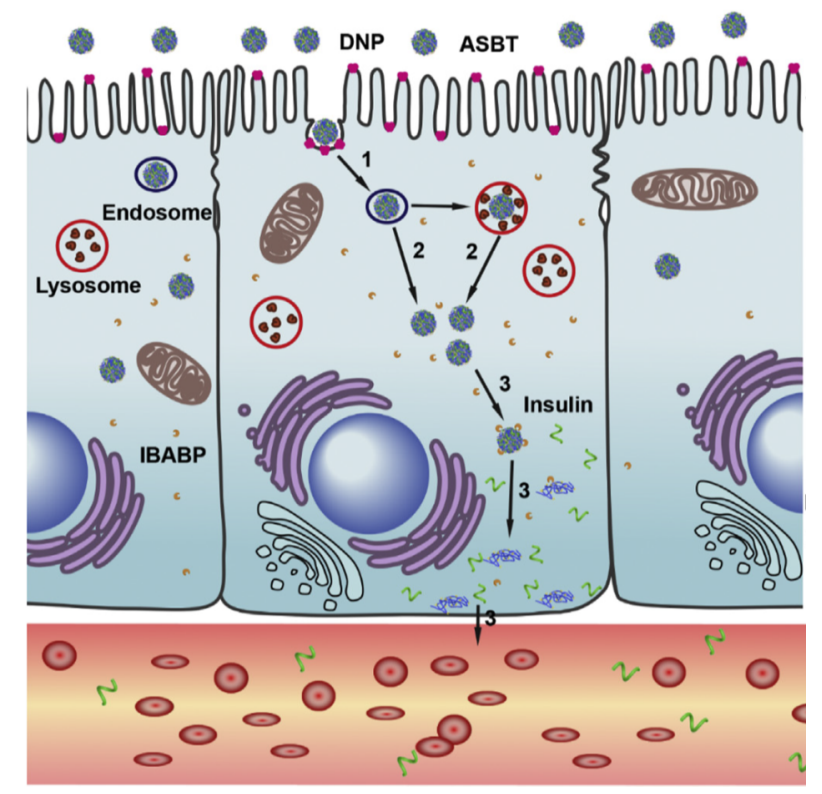

Figure 10. Deoxycholic acid functionalized chitosan NPs are able to pass the apical membrane of the endothelium by ASBT-mediated endocytosis in the first step. Then they also bypass the lysosomal degradation as the second barrier in a process called endolysosomal escape. Thirdly, they pass the basolateral membrane and insulin is released in the systemic circulation. Reprinted with permission from [92].

Another method is modification of other nanomaterials, e.g., polymeric or metallic nanoparticles, upon which polymeric compounds are applied to control the drug release in human body. As an example, biological synthesis of $\mathrm{SnO}_{2} \mathrm{NPs}$ using mammalian cells has numerous advantages of such materials such as low-cost and ecofriendly. According to this synthetic approach, metal binding peptides (i.e., VMNHWQEDLMFGY), which are extracted from MCF-7 human cancer cells, are used in $\mathrm{SnO}_{2} \mathrm{NPs}$ synthesis process. Biomineralization of $\mathrm{SnO}_{2} \mathrm{NPs}$ is accomplished by metal binding peptides that act as induction agents. Within the synthesis process, some functional groups with extra electrons to donate and metal binding sites of these peptides start a series of interactions with $\mathrm{Sn}^{2+}$ ions 
and aid $\mathrm{SnO}_{2} \mathrm{NPs}$ to grow with no increase in the toxic redox and capping agents. Another important advantage of peptides is high reactivity trait under aqueous conditions at room temperature that makes the synthesis procedure easy to perform. The results demonstrated that the shape, size, and 3D structures of $\mathrm{SnO}_{2}$ NPs could be restrained by regulating two parameters, i.e., reactants' concentration and the $\mathrm{pH}$. Good biocompatibility and high antibacterial properties are the two other benefits of peptides and $\mathrm{SnO}_{2}$ NPs combination [93].

\section{Conclusions and Perspective}

Bacterial adhesion and biofilm formation along with the emergence of multi-drug resistant bacteria have increased the global concern of several types of infection which could threaten the human health as well as impose huge costs to governments. These factors make it inevitable to develop and exploit on novel strategies for the production of new types of antimicrobial materials. In this regard, the use of surface functionalized nano-platforms has been introduced as a promising strategy that could provide strong anti-microbial activities for a wide range of applications, from medical tools to food management, personal care, and even water treatments. Surface functionalization is a bunch of actions to induce new properties to several types of nanomaterials which are created by the attachment of functional moieties to the surface of nano-platforms. These acts enable the nanomaterials to tune their features to suit various applications. This article addressed several modifications used for functionalization of polymeric and composite nano-platforms to provide them for two main applications; anti-microbial materials and drug delivery agents.

One of the newest methods for preparing anti-microbial surfaces is established based on mimicking the natural substances. In this class of materials, engineering the surface properties of materials (like shape, surface roughness, and the hydrophobic/hydrophilic property) via attachment of the functionalizing agents is a brilliant method that leads to the production of a surface with intrinsic anti-bacterial and anti-fouling properties. Also, this could prevent the bacterial attachment and kill them via membrane destruction. The combination use of engineered antimicrobial surface and antibacterial nanoparticles (like metal oxide nanoparticles) could result in super anti-microbial nanocomposites with additive or synergistic antimicrobial effects against infections [94,95]. Regardless of the mentioned approaches and applications, the use of functionalized surfaces could be also considered as an ideal choice for intelligent food packaging markets for preventing the spoilage of food through acting as anti-microbial agents, however, more investigation is required for this application [96,97]. Again, using the surface engineered nanomaterials as anti-fouling coatings for ceramics, tiles, enamel and architectural paints are the other attractive applications of these materials that received much attention from hospitals and other public places in the recent years [98,99]. Indeed, this is only one type of biomimetic method that could enhance the efficiency and reduce the side effect of nanomaterials.

Indeed, surface engineered nanomaterials could be used in different forms of drug delivery vehicles to not only enhance their properties such as bioavailability, hydrophilicity, biocompatibility, biodegradability, and drug-controlled release, but also offering new traits e.g., targeting ability, increasing safety, reducing dose and lowering the risk of possible side effects of theranostic features $[100,101]$. Some practical examples in this respect are drug delivery systems using new types of pads and scaffolds for tissue regenerations as well as several types of nano-platforms for diagnosis and treatment of hardly-curable diseases like cancer and neurodegenerative disease [102,103]. The combination therapy (also known as multi-modal therapy) is another strategy of using functionalizing agents in the preparation of drug delivery systems, in which two or more types of drugs or therapeutic methods are combined to gain treatment efficiency [104,105]. Smart nano-drug delivery systems can also be created using a surface modification approach. In these systems, nanoparticles with the ability of drug release in response to a specific feature present in the environment of the target tissue are used [106]. Smart delivery particles have the potential to imitate the physiological release behavior of agents and liberate the desired amount of the therapeutic where and when is 
needed. Also, these intelligent nanosystems recently have been applied as smart nano-theranostic, prepared from smart polymers (as targeted therapeutic carrier) and imaging agents [107].

Author Contributions: M.D. and M.G. wrote Section 1; M.D., M.G., E.N.Z., P.M., wrote and revised Section 2; A.Z., R.M., Z.B.T., M.A. F.R., and G.P. wrote and revised Section 3; A.Z., T.A., V.V.T.P., B.M., and P.M. wrote Section 4; A.B., M.S., T.K.M., P.M. wrote abstract and revised the whole manuscript. All authors have read and agreed to the published version of the manuscript.

Funding: M.D. was supported by PON CCI 2014IT16M2OP005 from the Italian Ministry of University and Research. B.M. gratefully acknowledges partial financial support from the Shahid Chamran University of Ahvaz. V. V.T.P. would like to gratefully acknowledge financial support under the "Project Hybrid Materials for Hierarchical Structures (HyHi, Reg. No. CZ.02.1.01/0.0/0.0/16_019/0000843), and Research Infrastructure NanoEnviCz (Project No. LM2018124) supported by the Ministry of Education, Youth and Sports of the Czech Republic and European Union-European Structural and Investment Funds in the frames of Operational Program Research, Development, and Education.

Conflicts of Interest: The authors declare no conflict of interest.

\section{Abbreviations}

AMPs: Antimicrobial peptides; BisGMA/TEGDMA: Glycerolate dimethacrylate/triethylene glycol dimethacrylate; BCD: Bcyclodextrin; CD44: Cluster determinant 44; DOX: Doxorubicin; FAS: Fluoroalkyl silane; GSNO: S-nitrosoglutathione; GSH: Glutathione; HARE: Hyaluronan receptor for endocytosis; ICG: Indocyanine green; MI-dPG: Mussel-inspired dendritic polyglycerol; MCF-7: Michigan Cancer Foundation 7 (cancercells); PE: Polyethylene; PEIs: Polyethylenimines; PLGA: Poly (D, L-lactic-co-glycolic acid); PP: Polypropylene; PPC: Poly (propylene carbonate); PPO-PEO-PPO: Polyethylene oxide-polypropylene oxide- polyethylene oxide copolymer; PS: Polystyrene; PU: Polyurethane; PVDF-HFP: Poly(vinylidene fluoride-co-hexafluoropropylene); PVP: Poly (N-vinylpyrrolidone); PS: Polystyrene; ROS: Reactive oxygen species; RPU: Rigid polyurethane; SEBS: Styrene-b-(ethyleneco-butylene)-b-styrene elastomer; SFL-RPU: Surface functionalized lignin-based rigid polyurethane; TPA: Terephthalaldehyde; QACs: Quaternary ammonium compounds; 5-FU: 5-fluorouracil.

\section{References}

1. Vesel, A.; Mozetic, M. New developments in surface functionalization of polymers using controlled plasma treatments. J. Phys. D Appl. Phys. 2017, 50, 293001. [CrossRef]

2. Samareh Fekri, H.; Ranjbar, M.; Pardakhty, A. A Systematic Study of Cu Nanospheres Embedded in Non-ionic Surfactant-Based Vesicle: Photocatalytic Efficiency and In Vivo Imaging Study. J. Clust. Sci. 2019, 30, 561-570. [CrossRef]

3. Leon-Garzon, A.R.; Dotelli, G.; Tommasini, M.; Bianchi, C.L.; Pirola, C.; Villa, A.; Lucotti, A.; Sacchi, B.; Barbieri, L. Experimental Characterization of Polymer Surfaces Subject to Corona Discharges in Controlled Atmospheres. Polymers 2019, 11, 1646. [CrossRef]

4. Ghorbani, F.; Zamanian, A.; Aidun, A. Conductive electrospun polyurethane-polyaniline scaffolds coated with poly (vinyl alcohol)-GPTMS under oxygen plasma surface modification. Mater. Today Commun. 2020, 22, 100752. [CrossRef]

5. Yáñez-Pacios, A.J.; Martín-Martínez, J.M. Surface modification and adhesion of wood-plastic composite (WPC) treated with UV/ozone. Compos. Interfaces 2018, 25, 127-149. [CrossRef]

6. Kehrer, M.; Duchoslav, J.; Hinterreiter, A.; Mehic, A.; Stehrer, T.; Stifter, D. Surface functionalization of polypropylene using a cold atmospheric pressure plasma jet with gas water mixtures. Surf. Coat. Technol. 2020, 384, 125170. [CrossRef]

7. Kurusu, R.S.; Demarquette, N.R. Surface modification to control the water wettability of electrospun mats. Int. Mater. Rev. 2019, 64, 249-287. [CrossRef]

8. Yao, M.; Tijing, L.D.; Naidu, G.; Kim, S.-H.; Matsuyama, H.; Fane, A.G.; Shon, H.K. A review of membrane wettability for the treatment of saline water deploying membrane distillation. Desalination 2020, 479, 114312. [CrossRef]

9. Manoudis, P.N.; Karapanagiotis, I. Modification of the wettability of polymer surfaces using nanoparticles. Prog. Org. Coat. 2014, 77, 331-338. [CrossRef]

10. Sham, M.L.; Li, J.; Ma, P.C.; Kim, J.-K. Cleaning and functionalization of polymer surfaces and nanoscale carbon fillers by UV/ozone treatment: A review. J. Compos. Mater. 2009, 43, 1537-1564. [CrossRef]

11. Mozetič, M. Surface Modification to Improve Properties of Materials; MDPI: Basel, Switzerland, 2019. 
12. Jamaledin, R.; Yiu, C.K.Y.; Zare, E.N.; Niu, L.; Vecchione, R.; Chen, G.; Gu, Z.; Tay, F.R.; Makvandi, P. Advances in antimicrobial microneedle patches for combating infections. Adv. Mater. 2020, in press. [CrossRef]

13. Nazarzadeh Zare, E.; Makvandi, P.; Borzacchiello, A.; Tay, F.R.; Ashtari, B.; Padil, V.T.V. Antimicrobial gum bio-based nanocomposites and their industrial and biomedical applications. Chem. Commun. 2019, 55, 14871-14885. [CrossRef] [PubMed]

14. Makvandi, P.; Pollini, M.; Gallo, A.L.; Maffezzoli, A.; Esposito Corcione, C.; Montagna, F.; Paladini, F.; Jamaledin, R. Antimicrobial modified hydroxyapatite composite dental bite by stereolithography. Polym. Adv. Technol. 2017, 29, 364-371. [CrossRef]

15. Makvandi, P.; Jamaledin, R.; Jabbari, M.; Nikfarjam, N.; Borzacchiello, A. Antibacterial quaternary ammonium compounds in dental materials: A systematic review. Dent. Mater. 2018, 34, 851-867. [CrossRef] [PubMed]

16. Makvandi, P.; Gu, J.T.; Zare, E.N.; Ashtari, B.; Moeini, A.; Tay, F.R.; Niu, L. Polymeric and inorganic nanoscopical antimicrobial fillers in dentistry. Acta Biomater. 2019, in press. [CrossRef] [PubMed]

17. Chaker, A.; Boufi, S. Cationic nanofibrillar cellulose with high antibacterial properties. Carbohydr. Polym. 2015, 131, 224-232. [CrossRef]

18. Fu, X.; Shen, Y.; Jiang, X.; Huang, D.; Yan, Y. Chitosan derivatives with dual-antibacterial functional groups for antimicrobial finishing of cotton fabrics. Carbohydr. Polym. 2011, 85, 221-227. [CrossRef]

19. Kim, Y.H.; Choi, H.-M.; Yoon, J.H. Synthesis of a Quaternary Ammonium Derivative of Chitosan and Its Application to a Cotton Antimicrobial Finish. Text. Res. J. 2008, 68, 428-434. [CrossRef]

20. Makvandi, P.; Ali, G.W.; Della Sala, F.; Abdel-Fattah, W.I.; Borzacchiello, A. Hyaluronic acid/corn silk extract based injectable nanocomposite: A biomimetic antibacterial scaffold for bone tissue regeneration. Mater. Sci. Eng. C 2019, 107, 10195. [CrossRef]

21. Makvandi, P.; Ali, G.W.; Della Sala, F.; Abdel-Fattah, W.I.; Borzacchiello, A. Biosynthesis and characterization of antibacterial thermosensitive hydrogels based on corn silk extract, hyaluronic acid and nanosilver for potential wound healing. Carbohydr. Polym. 2019, 223, 115023. [CrossRef]

22. Zare, E.N.; Makvandi, P. Antimicrobial Metal-Based Nanomaterials and Their Industrial and Biomedical Applications. In Engineered Antimicrobial Surfaces; Snigdha, S., Thomas, S., Radhakrishnan, E., Kalarikkal, N., Eds.; Springer: Berlin/Heidelberg, Germany, 2020; pp. 123-134.

23. Wang, C.; Makvandi, P.; Zare, E.N.; Tay, F.R.; Niu, L. Advances in antimicrobial organic and inorganic nanocompounds in biomedicine. Adv. Ther. 2020, in press. [CrossRef]

24. Makvandi, P.; Wang, C.; Zare, E.N.; Borzacchiello, A.; Niu, L.; Tay, F.R. Metal-based nanomaterials in biomedical applications: Antimicrobial activity and cytotoxicity aspects. Adv. Funct. Mater. 2020, in press. [CrossRef]

25. Dakal, T.C.; Kumar, A.; Majumdar, R.S.; Yadav, V. Mechanistic basis of antimicrobial actions of silver nanoparticles. Front. Microbiol. 2016, 7, 1831. [CrossRef] [PubMed]

26. Nicolau, D.P.; Belliveau, P.P.; Nightingale, C.H.; Quintiliani, R.; Freeman, C.D. Implementation of a once-daily aminoglycoside program in a large community-teaching hospital. Hosp. Pharm. 1995, 30, 674-676.

27. Zhan, J.; Wang, L.; Zhu, Y.; Gao, H.; Chen, Y.; Chen, J.; Jia, Y.; He, J.; Fang, Z.; Zhu, Y.; et al. TemperatureControlled Reversible Exposure and Hiding of Antimicrobial Peptides on an Implant for Killing Bacteria at Room Temperature and Improving Biocompatibility in Vivo. ACS Appl. Mater. Interfaces 2018, 10, 35830-35837. [CrossRef]

28. Ye, W.; Shi, Q.; Hou, J.; Jin, J.; Fan, Q.; Wong, S.-C.; Xu, X.; Yin, J. Superhydrophobic coating of elastomer on different substrates using a liquid template to construct a biocompatible and antibacterial surface. J. Mater. Chem. B 2014, 2, 7186-7191. [CrossRef]

29. Makvandi, P.; Ghaemy, M.; Ghadiri, A.A.; Mohseni, M. Photocurable, Antimicrobial Quaternary Ammonium-modified Nanosilica. J. Dent. Res. 2015, 94, 1401-1407. [CrossRef]

30. Ramyadevi, J.; Jeyasubramanian, K.; Marikani, A.; Rajakumar, G.; Rahuman, A.A. Synthesis and antimicrobial activity of copper nanoparticles. Mater. Lett. 2012, 71, 114-116. [CrossRef]

31. Kruk, T.; Szczepanowicz, K.; Stefańska, J.; Socha, R.P.; Warszyński, P. Synthesis and antimicrobial activity of monodisperse copper nanoparticles. Coll. Surf. B Biointerfaces 2015, 128, 17-22. [CrossRef]

32. Li, M.; Gao, L.; Schlaich, C.; Zhang, J.; Donskyi, I.S.; Yu, G.; Li, W.; Tu, Z.; Rolff, J.; Schwerdtle, T. Construction of functional coatings with durable and broad-spectrum antibacterial potential based on mussel-inspired dendritic polyglycerol and in situ-formed copper nanoparticles. ACS Appl. Mater. Interfaces 2017, 9, 35411-35418. [CrossRef] 
33. Pearson, H.A.; Urban, M.W. Simple click reactions on polymer surfaces leading to antimicrobial behavior. J. Mater. Chem. B 2014, 2, 2084-2087. [CrossRef] [PubMed]

34. Gu, H.; Ho, P.-L.; Tsang, K.W.T.; Wang, L.; Xu, B. Using Biofunctional Magnetic Nanoparticles to Capture Vancomycin-Resistant Enterococci and Other Gram-Positive Bacteria at Ultralow Concentration. J. Am. Chem. Soc. 2003, 125, 15702-15703. [CrossRef]

35. Ye, S.; Jiang, L.; Wu, J.; Su, C.; Huang, C.; Liu, X.; Shao, W. Flexible Amoxicillin-Grafted Bacterial Cellulose Sponges for Wound Dressing: In Vitro and in Vivo Evaluation. ACS Appl. Mater. Interfaces 2018, 10, 5862-5870. [CrossRef] [PubMed]

36. Bahramian, B.; Chrzanowski, W.; Kondyurin, A.; Thomas, N.; Dehghani, F. Fabrication of Antimicrobial Poly(propylene carbonate) Film by Plasma Surface Modification. Ind. Eng. Chem. Res. 2017, 56, 12578-12587. [CrossRef]

37. Liu, C.-Y.; Huang, C.-J. Functionalization of Polydopamine via the Aza-Michael Reaction for Antimicrobial Interfaces. Langmuir 2016, 32, 5019-5028. [CrossRef] [PubMed]

38. Fadida, T.; Kroupitski, Y.; Peiper, U.M.; Bendikov, T.; Sela Saldinger, S.; Poverenov, E. Air-ozonolysis to generate contact active antimicrobial surfaces: Activation of polyethylene and polystyrene followed by covalent graft of quaternary ammonium salts. Coll. Surf. B Biointerfaces 2014, 122, 294-300. [CrossRef]

39. Bastarrachea, L.J.; Goddard, J.M. Development of antimicrobial stainless steel via surface modification with N-halamines: Characterization of surface chemistry and N-halamine chlorination. J. Appl. Polym. Sci. 2013, 127, 821-831. [CrossRef]

40. Zhou, H.; Wang, H.; Niu, H.; Gestos, A.; Lin, T. Robust, self-healing superamphiphobic fabrics prepared by two-step coating of fluoro-containing polymer, fluoroalkyl silane, and modified silica nanoparticles. Adv. Funct. Mater. 2013, 23, 1664-1670. [CrossRef]

41. Zhang, X.; Jeremic, D.; Kim, Y.; Street, J.; Shmulsky, R. Effects of surface functionalization of lignin on synthesis and properties of rigid bio-based polyurethanes foams. Polymers 2018, 10, 706. [CrossRef]

42. Li, Y.; Ragauskas, A.J. Kraft lignin-based rigid polyurethane foam. J. Wood Chem. Technol. 2012, 32, $210-224$. [CrossRef]

43. Jenkins, J.; Mantell, J.; Neal, C.; Gholinia, A.; Verkade, P.; Nobbs, A.H.; Su, B. Antibacterial effects of nanopillar surfaces are mediated by cell impedance, penetration and induction of oxidative stress. Nat. Commun. 2020, 11,1-14. [CrossRef] [PubMed]

44. Singh, A.V.; Baylan, S.; Park, B.-W.; Richter, G.; Sitti, M. Hydrophobic pinning with copper nanowhiskers leads to bactericidal properties. PLoS ONE 2017, 12, e0175428. [CrossRef] [PubMed]

45. Prosdocimi, M.; Bevilacqua, C. Exogenous hyaluronic acid and wound healing: An updated vision. Panminerva Med. 2012, 54, 129-135. [PubMed]

46. Wang, X.; Xiang, Q.; Cao, W.; Jin, F.; Peng, X.; Hu, B.; Xing, X. Fabrication of magnetic nanoparticles armed with quaternarized N-halamine polymers as recyclable antibacterial agents. J. Biomater. Sci. Polym. Ed. 2016, 27, 1909-1925. [CrossRef]

47. Sankarganesh, M.; Jose, P.A.; Raja, J.D.; Kesavan, M.P.; Vadivel, M.; Rajesh, J.; Jeyamurugan, R.; Kumar, R.S.; Karthikeyan, S. New pyrimidine based ligand capped gold and platinum nano particles: Synthesis, characterization, antimicrobial, antioxidant, DNA interaction and in vitro anticancer activities. J. Photochem. Photobiol. B Biol. 2017, 176, 44-53. [CrossRef]

48. Carpenter, A.W.; Worley, B.V.; Slomberg, D.L.; Schoenfisch, M.H. Dual action antimicrobials: Nitric oxide release from quaternary ammonium-functionalized silica nanoparticles. Biomacromolecules 2012, 13, 3334-3342. [CrossRef]

49. Batista, C.C.S.; Albuquerque, L.J.C.; de Araujo, I.; Albuquerque, B.L.; da Silva, F.D.; Giacomelli, F.C. Antimicrobial activity of nano-sized silver colloids stabilized by nitrogen-containing polymers: The key influence of the polymer capping. RSC Adv. 2018, 8, 10873-10882. [CrossRef]

50. Wongpreecha, J.; Polpanich, D.; Suteewong, T.; Kaewsaneha, C.; Tangboriboonrat, P. One-pot, large-scale green synthesis of silver nanoparticles-chitosan with enhanced antibacterial activity and low cytotoxicity. Carbohydr. Polym. 2018, 199, 641-648. [CrossRef]

51. Liu, Z.; Wang, Y.; Zu, Y.; Fu, Y.; Li, N.; Guo, N.; Liu, R.; Zhang, Y. Synthesis of polyethylenimine (PEI) functionalized silver nanoparticles by a hydrothermal method and their antibacterial activity study. Mater. Sci. Eng. C 2014, 42, 31-37. [CrossRef] 
52. Lee, J.; Yoo, J.; Kim, J.; Jang, Y.; Shin, K.; Ha, E.; Ryu, S.; Kim, B.-G.; Wooh, S.; Char, K. Development of Multimodal Antibacterial Surfaces Using Porous Amine-Reactive Films Incorporating Lubricant and Silver Nanoparticles. ACS Appl. Mater. Interfaces 2019, 11, 6550-6560. [CrossRef]

53. Ben-Sasson, M.; Zodrow, K.R.; Genggeng, Q.; Kang, Y.; Giannelis, E.P.; Elimelech, M. Surface functionalization of thin-film composite membranes with copper nanoparticles for antimicrobial surface properties. Environ. Sci. Technol. 2014, 48, 384-393. [CrossRef] [PubMed]

54. Liao, Y.; Wang, Y.; Feng, X.; Wang, W.; Xu, F.; Zhang, L. Antibacterial surfaces through dopamine functionalization and silver nanoparticle immobilization. Mater. Chem. Phys. 2010, 121, 534-540. [CrossRef]

55. Xiang, Y.; Li, J.; Liu, X.; Cui, Z.; Yang, X.; Yeung, K.W.K.; Pan, H.; Wu, S. Construction of poly(lactic-co-glycolic acid)/ZnO nanorods/Ag nanoparticles hybrid coating on Ti implants for enhanced antibacterial activity and biocompatibility. Mater. Sci. Eng. C 2017, 79, 629-637. [CrossRef] [PubMed]

56. Li, Y.; Liu, L.; Wan, P.; Zhai, Z.; Mao, Z.; Ouyang, Z.; Yu, D.; Sun, Q.; Tan, L.; Ren, L. Biodegradable Mg-Cu alloy implants with antibacterial activity for the treatment of osteomyelitis: In vitro and in vivo evaluations. Biomaterials 2016, 106, 250-263. [CrossRef] [PubMed]

57. Battisti, M.; Vecchione, R.; Casale, C.; Pennacchio, F.A.; Lettera, V.; Jamaledin, R.; Profeta, M.; Di Natale, C.; Imparato, G.; Urciuolo, F. Non-invasive production of multi-compartmental biodegradable polymer microneedles for controlled intradermal drug release of labile molecules. Front. Bioeng. Biotechnol. 2019, 7, 296. [CrossRef]

58. Jamaledin, R.; di Natale, C.; Onesto, V.; Taraghdari, Z.B.; Zare, E.N.; Makvandi, P.; Vecchione, R.; Netti, P.A. Progress in Microneedles-mediated Protein Delivery. J. Clin. Med. 2020, 2, 542. [CrossRef]

59. Yang, J.S.; Xie, Y.J.; He, W. Research progress on chemical modification of alginate: A review. Carbohydr. Polym. 2011, 84, 33-39. [CrossRef]

60. Cu, Y.; Saltzman, W.M. Controlled Surface Modification with Poly(ethylene)glycol Enhances Diffusion of PLGA Nanoparticles in Human Cervical Mucus. Mol. Pharm. 2009, 6, 173-181. [CrossRef] [PubMed]

61. Park, J.; Fong, P.M.; Lu, J.; Russell, K.S.; Booth, C.J.; Saltzman, W.M.; Fahmy, T.M. PEGylated PLGA nanoparticles for the improved delivery of doxorubicin. Nanomed. Nanotechnol. Biol. Med. 2009, 5, 410-418. [CrossRef]

62. Nafee, N.; Taetz, S.; Schneider, M.; Schaefer, U.F.; Lehr, C.M. Chitosan-coated PLGA nanoparticles for DNA/RNA delivery: Effect of the formulation parameters on complexation and transfection of antisense oligonucleotides. Nanomed. Nanotechnol. Biol. Med. 2007, 3, 173-183. [CrossRef]

63. Mayol, L.; Biondi, M.; Russo, L.; Malle, B.M.; Schwach-Abdellaoui, K.; Borzacchiello, A. Amphiphilic hyaluronic acid derivatives toward the design of micelles for the sustained delivery of hydrophobic drugs. Carbohydr. Polym. 2014, 102, 110-116. [CrossRef] [PubMed]

64. Lee, M.Y.; Yang, J.A.; Jung, H.S.; Beack, S.; Choi, J.E.; Hur, W.; Koo, H.; Kim, K.; Yoon, S.K.; Hahn, S.K. Hyaluronic acid-gold nanoparticle/interferon $\alpha$ complex for targeted treatment of hepatitis $\mathrm{C}$ virus infection. ACS Nano 2012, 6, 9522-9531. [CrossRef] [PubMed]

65. Kim, C.; Jeong, D.; Kim, S.; Kim, Y.; Jung, S. Cyclodextrin functionalized agarose gel with low gelling temperature for controlled drug delivery systems. Carbohydr. Polym. 2019, 222, 115011. [CrossRef]

66. Fekri, H.S.; Ranjbar, M.; Noudeh, G.D.; Ziasistani, N. Green synthesis of strontium nanoparticles self-assembled in the presence of carboxymethyl cellulose: An in vivo imaging study. Luminescence 2019, 34, 870-876. [CrossRef] [PubMed]

67. Tavakol, S.; Ashrafizadeh, M.; Deng, S.; Azarian, M.; Abdoli, A.; Motavaf, M.; Poormoghadam, D.; Khanbabaei, H.; Ghasemipour Afshar, E.; Mandegary, A. Autophagy modulators: Mechanistic aspects and drug delivery systems. Biomolecules 2019, 9, 530. [CrossRef] [PubMed]

68. Li, Y.; Hong, W.; Zhang, H.; Zhang, T.T.; Chen, Z.; Yuan, S.; Peng, P.; Xiao, M.; Xu, L. Photothermally triggered cytosolic drug delivery of glucose functionalized polydopamine nanoparticles in response to tumor microenvironment for the GLUT1-targeting chemo-phototherapy. J. Control. Release 2020, 317, 232-245. [CrossRef] [PubMed]

69. Mohammadinejad, R.; Kumar, A.; Ranjbar-Mohammadi, M.; Ashrafizadeh, M.; Han, S.S.; Khang, G.; Roveimiab, Z. Recent Advances in Natural Gum-Based Biomaterials for Tissue Engineering and Regenerative Medicine: A Review. Polymers 2020, 12, 176. [CrossRef] 
70. Liao, S.-C.; Ting, C.-W.; Chiang, W.-H. Functionalized polymeric nanogels with $\mathrm{pH}$-sensitive benzoic-imine cross-linkages designed as vehicles for indocyanine green delivery. J. Coll. Interface Sci. 2020, 561, 11-22. [CrossRef] [PubMed]

71. Smyth, P.; Gibson, T.J.; Irvine, G.; Black, G.; Lavery, D.; Semsarilar, M.; Scott, C.J.; Themistou, E. pH-Responsive benzaldehyde-functionalized PEG-based polymeric nanoparticles for drug delivery: Effect of preparation method on morphology, dye encapsulation and attachment. Eur. Polym. J. 2020, 124, 109471. [CrossRef]

72. Wu, W.; Chen, M.; Luo, T.; Fan, Y.; Zhang, J.; Zhang, Y.; Zhang, Q.; Sapin-Minet, A.; Gaucher, C.; Xia, X. ROS and GSH-responsive S-nitrosoglutathione functionalized polymeric nanoparticles to overcome multidrug resistance in cancer. Acta Biomater. 2020, 103, 259-271. [CrossRef]

73. Peng, H.; Huang, X.; Melle, A.; Karperien, M.; Pich, A. Redox-responsive degradable prodrug nanogels for intracellular drug delivery by crosslinking of amine-functionalized poly ( $\mathrm{N}$-vinylpyrrolidone) copolymers. J. Coll. Interface Sci. 2019, 540, 612-622. [CrossRef] [PubMed]

74. Wang, W.; Wu, Z.; Lin, X.; Si, T.; He, Q. Gold-nanoshell-functionalized polymer nanoswimmer for photomechanical poration of single-cell membrane. J. Am. Chem. Soc. 2019, 141, 6601-6608. [CrossRef] [PubMed]

75. Pourjavadi, A.; Bagherifard, M.; Doroudian, M. Synthesis of micelles based on chitosan functionalized with gold nanorods as a light sensitive drug delivery vehicle. Int. J. Biol. Macromol. 2020, 149, 809-818. [CrossRef]

76. Lin, A.; Giuliano, C.J.; Palladino, A.; John, K.M.; Abramowicz, C.; Yuan, M.L.; Sausville, E.L.; Lukow, D.A.; Liu, L.; Chait, A.R. Off-target toxicity is a common mechanism of action of cancer drugs undergoing clinical trials. Sci. Transl. Med. 2019, 11, eaaw8412. [CrossRef] [PubMed]

77. Ashrafizadeh, M.; Ahmadi, Z.; Kotla, N.G.; Afshar, E.G.; Samarghandian, S.; Mandegary, A.; Pardakhty, A.; Mohammadinejad, R.; Sethi, G. Nanoparticles targeting STATs in cancer therapy. Cells 2019, 8, 1158. [CrossRef] [PubMed]

78. Samarehfekri, H.; Ranjbar, M.; Pardakhty, A.; Amanatfard, A. Systematic Study of NaF Nanoparticles in Micelles loaded on Polylactic Acid Nanoscaffolds: In Vitro Efficient Delivery. J. Clust. Sci. 2020, 31, 453-461. [CrossRef]

79. Shakeri, S.; Ashrafizadeh, M.; Zarrabi, A.; Roghanian, R.; Afshar, E.G.; Pardakhty, A.; Mohammadinejad, R.; Kumar, A.; Thakur, V.K. Multifunctional Polymeric Nanoplatforms for Brain Diseases Diagnosis, Therapy and Theranostics. Biomedicines 2020, 8, 13. [CrossRef]

80. Riaz, M.K.; Riaz, M.A.; Zhang, X.; Lin, C.; Wong, K.H.; Chen, X.; Zhang, G.; Lu, A.; Yang, Z. Surface functionalization and targeting strategies of liposomes in solid tumor therapy: A review. Int. J. Mol. Sci. 2018, 19, 195. [CrossRef]

81. Chanphai, P.; Thomas, T.J.; Tajmir-Riahi, H.A. Application and biomolecular study of functionalized folic acid-dendrimer nanoparticles in drug delivery. J. Biomol. Struct. Dyn. 2020, 1-19. [CrossRef]

82. Ilhami, F.B.; Huang, S.-Y.; Chen, J.-K.; Kao, C.-Y.; Cheng, C.-C. Multifunctional adenine-functionalized supramolecular micelles for highly selective and effective cancer chemotherapy. Polym. Chem. 2020, 11, 849-856. [CrossRef]

83. Munzar, J.D.; Ng, A.; Juncker, D. Duplexed aptamers: History, design, theory, and application to biosensing. Chem. Soc. Rev. 2019, 48, 1390-1419. [CrossRef] [PubMed]

84. Saravanakumar, K.; Hu, X.; Shanmugam, S.; Chelliah, R.; Sekar, P.; Oh, D.-H.; Vijayakumar, S.; Kathiresan, K.; Wang, M.-H. Enhanced cancer therapy with $\mathrm{pH}$-dependent and aptamer functionalized doxorubicin loaded polymeric (poly D, L-lactic-co-glycolic acid) nanoparticles. Arch. Biochem. Biophys. 2019, 671, 143-151. [CrossRef] [PubMed]

85. Rață, D.M.; Cadinoiu, A.N.; Atanase, L.I.; Bacaita, S.E.; Mihalache, C.; Daraba, O.-M.; Gherghel, D.; Popa, M. "In vitro" behaviour of aptamer-functionalized polymeric nanocapsules loaded with 5-fluorouracil for targeted therapy. Mater. Sci. Eng. C 2019, 103, 109828. [CrossRef] [PubMed]

86. Kim, J.S.; Sirois, A.R.; Vazquez Cegla, A.J.; Jumai'an, E.; Murata, N.; Buck, M.E.; Moore, S.J. Protein-Polymer Conjugates Synthesized Using Water-Soluble Azlactone-Functionalized Polymers Enable Receptor-Specific Cellular Uptake toward Targeted Drug Delivery. Bioconj. Chem. 2019, 30, 1220-1231. [CrossRef]

87. Tian, T.; Zhang, H.-X.; He, C.-P.; Fan, S.; Zhu, Y.-L.; Qi, C.; Huang, N.-P.; Xiao, Z.-D.; Lu, Z.-H.; Tannous, B.A. Surface functionalized exosomes as targeted drug delivery vehicles for cerebral ischemia therapy. Biomaterials 2018, 150, 137-149. [CrossRef] [PubMed] 
88. Li, J.; Ai, Y.; Wang, L.; Bu, P.; Sharkey, C.C.; Wu, Q.; Wun, B.; Roy, S.; Shen, X.; King, M.R. Targeted drug delivery to circulating tumor cells via platelet membrane-functionalized particles. Biomaterials 2016, 76, 52-65. [CrossRef]

89. Ashrafizadeh, M.; Fekri, H.S.; Ahmadi, Z.; Farkhondeh, T.; Samarghandian, S. Therapeutic and biological activities of berberine: The involvement of Nrf2 signaling pathway. J. Cell. Biochem. 2020, 121, 1575-1585. [CrossRef]

90. Taraghdari, Z.B.; Imani, R.; Mohabatpour, F. A Review on Bioengineering Approaches to Insulin Delivery: A Pharmaceutical and Engineering Perspective. Macromol. Biosci. 2019, 19, 1800458. [CrossRef]

91. Khafagy, E.-S.; Morishita, M.; Onuki, Y.; Takayama, K. Current challenges in non-invasive insulin delivery systems: A comparative review. Adv. Drug Deliv. Rev. 2007, 59, 1521-1546. [CrossRef]

92. Fan, W.; Xia, D.; Zhu, Q.; Li, X.; He, S.; Zhu, C.; Guo, S.; Hovgaard, L.; Yang, M.; Gan, Y. Functional nanoparticles exploit the bile acid pathway to overcome multiple barriers of the intestinal epithelium for oral insulin delivery. Biomaterials 2018, 151, 13-23. [CrossRef]

93. Singh, A.V.; Jahnke, T.; Xiao, Y.; Wang, S.; Yu, Y.; David, H.; Richter, G.; Laux, P.; Luch, A.; Srivastava, A. Peptide-induced biomineralization of tin oxide $\left(\mathrm{SnO}_{2}\right)$ nanoparticles for antibacterial applications. J. Nanosci. Nanotechnol. 2019, 19, 5674-5686. [CrossRef] [PubMed]

94. Wang, J.; Vermerris, W. Antimicrobial nanomaterials derived from natural products-A review. Materials 2016, 9, 255. [CrossRef] [PubMed]

95. Tan, R.; Yoo, J.; Jang, Y. Engineering Approaches to Create Antibacterial Surfaces on Biomedical Implants and Devices. In Racing for the Surface; Springer: Berlin/Heidelberg, Germany, 2020; pp. 313-340.

96. Huang, K.-S.; Yang, C.-H.; Huang, S.-L.; Chen, C.-Y.; Lu, Y.-Y.; Lin, Y.-S. Recent advances in antimicrobial polymers: A mini-review. Int. J. Mol. Sci. 2016, 17, 1578. [CrossRef]

97. Vasile, C. Polymeric nanocomposites and nanocoatings for food packaging: A review. Materials 2018, $11,1834$. [CrossRef] [PubMed]

98. Anh, L.H.T.; Phuong, P.T.T.; Van, N.T.T.; Tri, N.; Minh, N.V.; Ha, H.K.P. Preparation of Ag/ $\mathrm{Zn}_{2} \mathrm{TiO}_{4}$ and its antibacterial activity on enamel tile. Chem. Pap. 2019, 73, 1019-1026. [CrossRef]

99. Le, T.T.; Nguyen, T.V.; Nguyen, T.A.; Nguyen, T.T.H.; Thai, H.; Dinh, D.A.; Nguyen, T.M. Thermal, mechanical and antibacterial properties of water-based acrylic Polymer $/ \mathrm{SiO}_{2}-\mathrm{Ag}$ nanocomposite coating. Mater. Chem. Phys. 2019, 232, 362-366. [CrossRef]

100. Calzoni, E.; Cesaretti, A.; Polchi, A.; Di Michele, A.; Tancini, B.; Emiliani, C. Biocompatible polymer nanoparticles for drug delivery applications in cancer and neurodegenerative disorder therapies. J. Funct. Biomater. 2019, 10, 4. [CrossRef]

101. Patel, P.; Hanini, A.; Shah, A.; Patel, D.; Patel, S.; Bhatt, P.; Pathak, Y. V Surface Modification of Nanoparticles for Targeted Drug Delivery. In Surface Modification of Nanoparticles for Targeted Drug Delivery; Springer: Berlin/Heidelberg, Germany, 2019; pp. 19-31.

102. Lahkar, S.; Das, M.K. Brain-Targeted Drug Delivery with Surface-Modified Nanoparticles. In Surface Modification of Nanoparticles for Targeted Drug Delivery; Springer: Berlin/Heidelberg, Germany, 2019; pp. 277-310.

103. Zhou, W.; Qiao, Z.; Zare, E.N.; Huang, J.; Zheng, X.; Sun, X.; Shao, M.; Wang, H.; Wang, X.; Chen, D.; et al. 4D-Printed Dynamic Materials in Biomedical Applications: Chemistry, Challenges, and Their Future Perspectives in the Clinical Sector. J. Med. Chem. 2020. [CrossRef]

104. Vogus, D.R.; Krishnan, V.; Mitragotri, S. A review on engineering polymer drug conjugates to improve combination chemotherapy. Curr. Opin. Coll. Interface Sci. 2017, 31, 75-85. [CrossRef]

105. Pushpalatha, R.; Selvamuthukumar, S.; Kilimozhi, D. Nanocarrier mediated combination drug delivery for chemotherapy-A review. J. Drug Deliv. Sci. Technol. 2017, 39, 362-371. [CrossRef]

106. Hajebi, S.; Rabiee, N.; Bagherzadeh, M.; Ahmadi, S.; Rabiee, M.; Roghani-Mamaqani, H.; Tahriri, M.; Tayebi, L.; Hamblin, M.R. Stimulus-responsive polymeric nanogels as smart drug delivery systems. Acta Biomater. 2019, 92, 1-18. [CrossRef] [PubMed]

107. Ain, Q.U. Current and Future Aspects of Smart Nanotheranostic Agents in Cancer Therapeutics. In Nanotheranostics; Springer: Berlin/Heidelberg, Germany, 2019; pp. 213-227.

(C) 2020 by the authors. Licensee MDPI, Basel, Switzerland. This article is an open access article distributed under the terms and conditions of the Creative Commons Attribution (CC BY) license (http://creativecommons.org/licenses/by/4.0/). 